\title{
O OVO EM PÓ NA ALIMENTAÇÃO DE LEITÕES RECÉM-DESMAMADOS
}

\author{
ADRIANA NOGUEIRA FIGUEIREDO
}

Dissertação apresentada à Escola

Superior de Agricultura "Luiz de Queiroz, Universidade de São Paulo, para obtenção do título de Mestre em Agronomia, Área de Concentração: Ciência Animal e Pastagens

\author{
PIRACICABA \\ Estado de São Paulo - Brasil \\ Maio - 2002
}




\title{
O OVO EM PÓ NA ALIMENTAÇÃO DE LEITÕES RECÉM-DESMAMADOS
}

\author{
ADRIANA NOGUEIRA FIGUEIREDO \\ Zootecnista
}

Orientador: Prof. Dr. VALDOMIRO SHIGUERU MIYADA

Dissertação apresentada à Escola Superior de Agricultura "Luiz de Queiroz, Universidade de São Paulo, para obtenção do título de Mestre em Agronomia, Área de Concentração: Ciência Animal e Pastagens

\section{PIRACICABA}

Estado de São Paulo - Brasil

$$
\text { Maio - } 2002
$$




\section{Dados Internacionais de Catalogação na Publicação (CIP) DIVISÃO DE BIBLIOTECA E DOCUMENTAÇÃO - ESALQ/USP}

Figueiredo, Adriana Nogueira

O ovo em pó na a limentação de leitões recém-desmamados/ Adriana Nogueira Figueiredo. - - Piracic aba, 2001.

$61 \mathrm{p}$.

Dissertação (mestra do) - - Esc ola Superior de Agric ultura Luiz de Queiroz, 2002.

Bibliografia.

1. Desmama animal 2. Dieta a nimal 3. Leitão 4. Nutrição animal I. Título

CDD 636.4084

"Permitida a cópia total ou parcial deste documento, desde que citada a fonte - $\mathrm{O}$ autor" 
PARA:

Meus pais Heraldo e Alda Maria,

Por toda a minha gratidão, admiração e amor;

Meus irmãos Guto, Xande e Jú, minha cunhada Mimi e meu afilhado Léo,

Por me fazerem acreditar sempre no significado da palavra família;

Sr. Wilson e D. Edna, meus futuros sogros,

Pelos exemplos de luta e fé;

COM MUITO CARINHO,

DEDICO

Ao Flavio,

Pelo companheirismo, cumplicidade, paciência e incentivo;

COM MUITO AMOR, OFEREÇO 


\section{AGRADECIMENTOS}

A Deus, por mais esta etapa cumprida.

Ao meu orientador Prof. Dr. Valdomiro Shigueru Miyada, pelos exemplos de profissionalismo, honestidade e justiça e pela confiança em mim depositada.

À Fundação de Amparo à Pesquisa do Estado de São Paulo - FAPESP, pela bolsa concedida para a realização deste trabalho.

Ao Prof. Dr. José Fernando Machado Menten, pela colaboração, sugestões e grande disponibilidade.

Aos Profs. do Departamento de Produção Animal da ESALQ, por todo o ensinamento compartilhado.

Aos funcionários do Setor de Suinocultura do Departamento de Produção Animal da ESALQ, Adão, Sr. Dito, Sr. Ventura e Sr. Pires, pelos agradáveis momentos de trabalho.

Às secretárias do Departamento de Produção Animal da ESALQ, Vera e Cláudia, por toda a ajuda e atenção.

Ao Flavio, Carlos Eduardo, José Otávio e Adriana pela colaboração, disposição e apoio em todos os momentos. 
Aos amigos e colegas de trabalho, Adriana, Carlos Eduardo, Liliana, Cláudia, José Otávio, Aline, Juliano, Simone, pela ótima convivência no decorrer do curso.

À doutoranda Cláudia Paz pelo auxílio nas análises estatísticas e pela atenção.

À Renata Duarte, pelas análises laboratoriais e pela amizade e confiança.

À Melissa Hannas, pela cooperação na realização desse trabalho.

À empresa SOHOVOS, pelo fornecimento do ovo em pó testado neste trabalho.

À empresa M CASSAB, pelo fornecimento do plasma sanguíneo.

À empresa SUPRE MAIS, pelo fornecimento de ingredientes para confecção das dietas experimentais.

E para todos aqueles que muito me auxiliaram para a realização de todo o programa de mestrado e que não estão aqui citados, o meu sincero agradecimento. 


\section{SUMÁRIO}

Página

LISTA DE FIGURAS......................................................................... viii

LISTA DE TABELAS......................................................................... ix

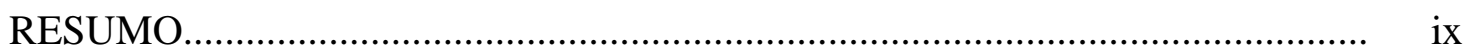

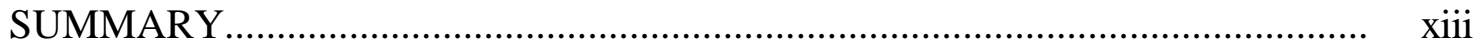

1 INTRODUÇÃ

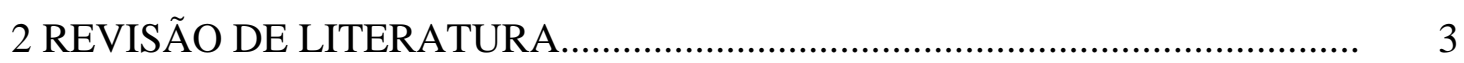

2.1 Alguns aspectos relacionados à nutrição de leitões....................................... 3

$2.2 \mathrm{O}$ plasma sanguíneo na alimentação de suínos.............................................. 5

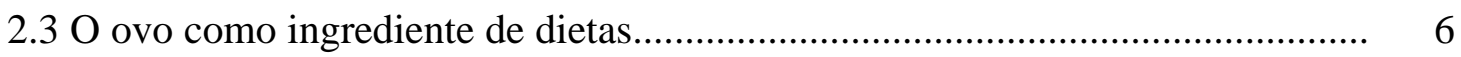

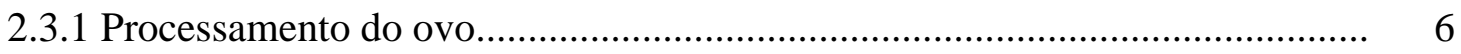

2.3.2 Valor nutricional e imunológico do ovo.................................................... 8

2.3.3 O ovo em pó na alimentação de suínos...................................................... 11

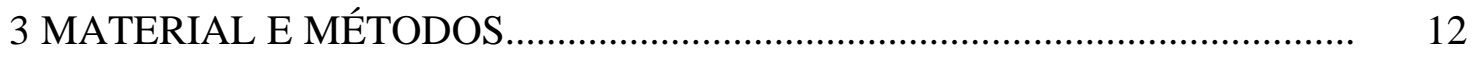

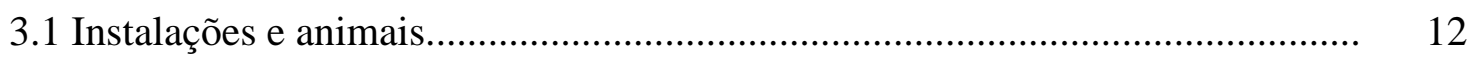

3.2 Ensaio de digestibilidade (Experimento I)................................................... 13

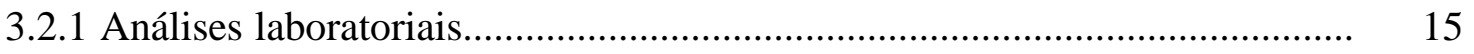

3.2.2 Determinação dos coeficientes de digestibilidade aparente de nutrientes e dos conteúdos de energia e proteína digestíveis......................................... 15 
Página

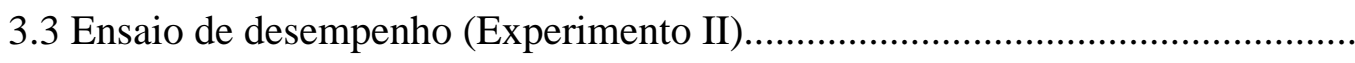

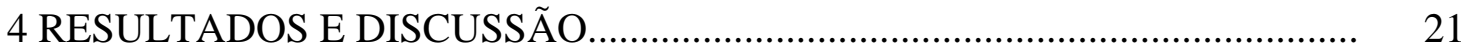

4.1 Ensaio de digestibilidade (Experimento I)............................................. 21

4.2 Ensaio de desempenho (Experimento II)................................................ 25

4.2.1 Características de desempenho............................................................. 25

4.2.2 Componentes plasmáticos e sanguíneos................................................. 35

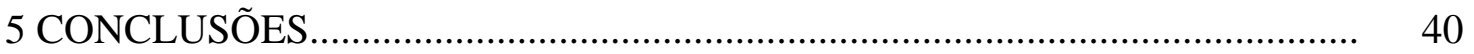

REFERÊNCIAS BIBLIOGRÁFICAS....................................................... 41

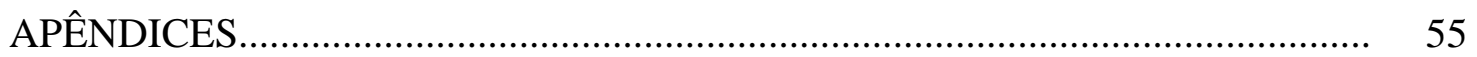




\section{LISTA DE FIGURAS}

Página

1 Efeito da substituição protéica do plasma sanguíneo pelo ovo em pó sobre o ganho diário de peso (GDP) de leitões durante a fase inicial de 15 a 28 dias

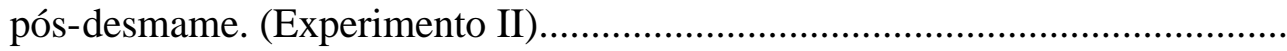

2 Efeito da substituição protéica do plasma sanguíneo pelo ovo em pó sobre o consumo diário de ração (CDR) de leitões durante a fase inicial de 15 a 28 dias pós-desmame. (Experimento II)..........................................................

3 Efeito da substituição protéica do plasma sanguíneo pelo ovo em pó sobre o peso aos 28 dias (P28) dos leitões. (Experimento II)

4 Efeito da substituição protéica do plasma sanguíneo pelo ovo em pó sobre o ganho diário de peso (GDP) em leitões durante o período total (1 a 28 dias pós-desmame). (Experimento II)

5 Efeito da substituição protéica do plasma sanguíneo pelo ovo em pó sobre o consumo diário de ração (CDR) de leitões durante o período total (1 a 28 dias pós-desmame). (Experimento II) 


\section{LISTA DE TABELAS}

Página

1 Composição percentual e valores calculados da dieta basal do ensaio de digestibilidade (Experimento I)............................................................. 14

2 Composição percentual e valores calculados das dietas experimentais fornecidas aos leitões na fase pré-inicial (1 a 14 dias pós-desmame). (Experimento II)

3 Composição percentual e valores calculados das dietas experimentais fornecidas aos leitões na fase inicial (15 a 28 dias pós-desmame). (Experimento II)

4 Composição química e valor energético do ovo em pó, expresso na matéria natural (Experimento I)

5 Valores dos coeficientes de digestibilidade aparente (CDap) de nutrientes e a energia e proteína digestíveis do ovo em pó. (Experimento I)

6 Valores médios dos tratamentos para peso inicial (PI), ganho diário de peso (GDP), consumo diário de ração (CDR), conversão alimentar (CA) e peso aos 14 dias (P14) dos leitões, referente à fase pré-inicial (1-14 dias pós-desmame) 26 (Experimento II). 
7 Valores médios dos tratamentos para ganho diário de peso (GDP), consumo diário de ração (CDR), conversão alimentar (CA) e peso aos 28 dias (P28) dos leitões, referentes à fase inicial (15-28 dias pós-desmame)

8 Valores médios dos tratamentos para ganho diário de peso (GDP), consumo diário de ração (CDR) e conversão alimentar (CA) dos leitões, referentes ao período total (0-28 dias pós-desmame).....

9 Valores médios dos tratamentos para os componentes plasmáticos e sanguíneos. (Experimento II).

A1 Cálculo de restrição alimentar durante o período de adaptação (Experimento I).

A2 Ganhos diários de pesos (GDP, kg), consumos diários de ração (CDR, kg) e conversões alimentares (CA) dos animais, referente à fase pré-inicial (1-14 dias pós-desmame) (Experimento II)

A3 Ganhos diários de pesos (GDP, kg), consumos diários de ração (CDR, kg) e conversões alimentares (CA) dos animais, referente à fase inicial (15-28 dias pós-desmame) (Experimento II).

A4 Ganhos diários de pesos (GDP, kg), consumos diários de ração (CDR, kg) e conversões alimentares (CA) dos animais, referente ao período total (1-28 dias pós-desmame) (Experimento II)

A5 Médias dos níveis plasmáticos de uréia (UR, mg/100ml), proteína total (PT, mg/100ml), albumina (AL, mg/100ml), globulina (GL mg/100ml), relação albumina/globulina (AL/GL), triglicérides (TG, mg/100ml) e colesterol (COL, mg/100ml) e dos níveis sanguíneos de hemoglobina (Hg, mg/100ml) e hematócrito (Ht, \%) (Experimento II). 


\title{
O OVO EM PÓ NA ALIMENTAÇÃO DE LEITÕES RECÉM-DESMAMADOS
}

\author{
Autora: ADRIANA NOGUEIRA FIGUEIREDO \\ Orientador: Prof. Dr.VALDOMIRO SHIGUERU MIYADA
}

\section{RESUMO}

Foram realizados dois experimentos para determinar a composição química, os coeficientes de digestibilidade de nutrientes e os valores de energia e proteína digestíveis do ovo em pó (OP) e avaliar o desempenho e os componentes sanguíneos e plasmáticos de leitões recém-desmamados alimentados com dietas contendo níveis crescentes de proteína do OP em substituição à proteína do plasma sanguíneo. O Experimento I consistiu de um ensaio de digestibilidade, sendo utilizados oito leitões (quatro machos castrados e quatro fêmeas), mestiços Landrace x Large White com 15,9 kg de peso médio. Os tratamentos consistiram de uma dieta basal e uma dieta teste ( $70 \%$ dieta basal $+30 \%$ OP) com quatro repetições cada. Utilizou-se a metodologia da coleta parcial de fezes com o uso de $0,5 \%$ de óxido crômico $\left(\mathrm{Cr}_{2} \mathrm{O}_{3}\right)$ adicionado às dietas como indicador. Os coeficientes de digestibilidade aparente do OP foram de 87,18, 80,76, 81,99 e 70, $54 \%$, respectivamente, para a matéria seca, energia bruta, proteína bruta e extrato etéreo. 
A partir dos coeficientes de digestibilidade determinados e os valores de proteína bruta $(56,53 \%)$ e energia bruta $(5.897 \mathrm{kcal} / \mathrm{kg})$ foram calculados os valores de $43,91 \%$ de proteína digestível e $5.139 \mathrm{kcal} / \mathrm{kg}$ de energia digestível do OP para leitões em fase de creche. No Experimento II, fram utilizados 90 animais (machos castrados e fêmeas), mestiços Landrace x Large White, desmamados com 24 dias e 5,6 kg de peso médio. O período experimental compreendeu duas fases, a pré-inicial (1 a 14 dias) e inicial (15 a 28 dias pós-desmame), onde os tratamentos consistiram de cinco rações isonutritivas com níveis crescentes $(0,25,50,75$ e 100\%) de substituição protéica do plasma sanguíneo da dieta pelo OP. O delineamento experimental foi o de blocos casualizados, com nove repetições por tratamento e dois animais por unidade experimental (baia). Os animais e a ração foram pesados para o cálculo do ganho diário de peso (GDP), consumo diário de ração (CDR) e conversão alimentar (CA) em cada fase e período total. Ao final do ensaio de desempenho foi retirada uma amostra de sangue de cada animal para a determinação dos componentes plasmáticos (uréia, proteína total, albumina, globulina, relação albumina/globulina, triglicérides e colesterol) e sanguíneos (hematócrito e hemoglobina). Não houve diferença entre os tratamentos $(P>0,05)$ para as variáveis de desempenho na fase de 1 a 14 dias pós-desmame. Para a segunda fase experimental e para o período total, foi observada uma redução linear $(\mathrm{P}<0,01)$ do GDP e CDR, à medida que aumentava o nível de substituição do PS pelo OP. Para as variáveis dos componentes plasmáticos e sanguíneos não foram observadas diferenças significativas $(\mathrm{P}>0,05)$ entre os tratamentos. Concluiu-se que o ovo em pó pode substituir completamente o plasma sanguíneo sem afetar o desempenho dos animais na fase de 1 a 14 dias pós-desmame, enquanto que na fase de 15 a 28 dias essa substituição prejudicou o desempenho dos animais, refletindo assim, em um pior desempenho no período total (1 a 28 dias). A inclusão crescente do ovo em pó nas dietas não alterou os componentes plasmáticos e sanguíneos. 


\title{
SPRAY-DRIED EGG FOR WEANLING PIGS
}

\author{
Author: ADRIANA NOGUEIRA FIGUEIREDO \\ Adviser: Prof. Dr.VALDOMIRO SHIGUERU MIYADA
}

\section{SUMMARY}

Two experiments were carried out to determine the chemical composition, nutrients digestibility and digestible energy and protein of spray-dried egg (OP) and to study the performance and plasma and blood components of weanling pigs fed a diets containing OP. In Experiment I, eight Landrace x Large White crossbred pigs (four barrows and four gilts), averaging $15.9 \mathrm{~kg}$ live weight were used for digestibility assay. The animals were assigned to two treatments and four replications/treatment. The treatments consisted of the basal diet and test diet (70\% of basal diet $+30 \%$ of OP) The method was the partial faeces collection, using $0.5 \%$ of chromium oxide $\left(\mathrm{Cr}_{2} \mathrm{O}_{3}\right)$ in the diet as fecal marker. The apparent digestibility coefficients of dry matter, gross energy, crude protein and crude fat were, respectivily, 87.18, 80.76, 81.99 and 70.54\%. From these results of apparent digestibility coeficients and the values of crude protein $(56.53 \%)$ and gross energy $(5,897 \mathrm{kcal} / \mathrm{kg})$ resulted in $43.91 \%$ of digestible protein and 
$5,139 \mathrm{kcal} / \mathrm{kg}$ of digestible energy for OP. In Experiment II, ninety Landrace $\mathrm{x}$ Large White crossbred pigs (barrows and gilts) were weaned at 24 days of age with 5,6 kg live weight. The experimental period was divided in two phases, 1 to 14 days and 15 to 28 days post-weaning. The treatments consisted of five dietary levels of $0,25,50,75$ and $100 \%$ of substitution of plasma protein for OP protein. Pigs were alloted in a randomized block design with nine replications per treatment and two pigs per experimental unit (pen). Pigs were weighed and the data of feed intake per pen were registered every week. Pig performance data such as average daily gain (GDP), daily feed intake (CDR) and feed conversion (CA) were analyzed by polynomial regression. No treatment effects $(\mathrm{P}>0.05)$ were observed on performance for 1-14 day postweaning phase. For the $15-28$ phase and for the total period, linear reductions $(\mathrm{P}<0.01)$ of GDP and CDR, were observed with increased dietary OP levels. No treatment effects $(\mathrm{P}>0.05)$ were observed on plasma and blood components. Therefore, it can be conclued that the spray-dried egg can completely replace plasma without affecting the performance of pigs during 1-14 day post-weaning phase. For the 15-28 day phase and total period, added OP levels showed a depressive effect on pig performance. The plasma and blood components were not affected by the inclusion of spray-dried egg 


\section{INTRODUÇÃO}

O desmame é um período crítico dentro do ciclo produtivo dos suínos. Isso porque o leitão desmamado apresenta os sistemas imunológico e digestório imaturos em um período de transição do alimento leite para uma ração seca, os quais, aliados ao estresse causado na desmama, prejudicam o desempenho do animal. Assim, a nutrição de leitões é uma área muito estudada, pois para suportar o crescimento e minimizar as perdas de desempenho é de grande importância que a dieta fornecida imediatamente após o desmame seja de alta digestibilidade, palatabilidade e concentração de nutrientes, uma vez que esses animais possuem um baixo consumo nesta fase.

Dentre os ingredientes de rações para suínos na fase inicial, o ovo aparece como uma opção a ser estudada, sendo considerado uma fonte de proteína animal de excelente qualidade, com todos os aminoácidos essenciais e distribuição balanceada de vitaminas e minerais (Egg Products, 2000). Além disso, a facilidade com que os ovos são trincados e quebrados produz uma quantidade substancial de subprodutos que são inúteis para o consumo humano. De acordo com Harmon et al. (2001), aproximadamente $2 \%$ de todos os ovos de galinhas poedeiras produzidos são rejeitados.

A desidratação dos ovos que são descartados para o consumo humano é uma alternativa para viabilizar a utilização desse ingrediente na formulação de rações para suínos. Com a introdução do processamento de alimentos de origem animal pelo método do spray-dry foi possível a obtenção de produtos de qualidade, mantendo íntegra suas características originais. Como exemplo, destaca-se o uso de produtos do sangue como o plasma na alimentação de leitões, promovendo resultados favoráveis a partir desse processamento. 
Há poucos relatos no Brasil sobre o uso do ovo desidratado por spray-dry (ovo em pó) na alimentação de suínos e as tabelas nacionais e estrangeiras não fazem sequer referência sobre a sua utilização. Assim, tendo conhecimento das propriedades nutricionais do ovo e sabendo da necessidade do leitão recém-desmamado em termos de exigências em nutrientes e qualidade dos ingredientes, torna-se pertinente a avaliação desse alimento alternativo.

Dessa forma, os objetivos dessa pesquisa foram: (a) determinar a composição química, os coeficientes de digestibilidade de nutrientes e os valores de energia e proteína digestíveis do ovo em pó; (b) avaliar o desempenho e os componentes sanguíneos e plasmáticos de leitões recém-desmamados alimentados com dietas contendo níveis crescentes de ovo em pó em substituição ao plasma sanguíneo 


\section{REVISÃO DE LITERATURA}

\subsection{Alguns aspectos relacionados à nutrição de leitões}

A suinocultura vem se expandindo rapidamente no Brasil e no mundo, graças aos avanços alcançados nos campos do melhoramento genético, nutrição, manejo, ambiência e sanidade. Entretanto, ainda existem alguns entraves para o sucesso completo da criação e, dentre estes, está o desmame dos leitões.

Hoje em dia, a idade de desmame dos leitões é cada vez mais reduzida, visando maximizar o potencial de produtividade das porcas. Dessa forma, os leitões são desmamados antes mesmo de serem capazes de produzir anticorpos suficientes para proteção contra doenças entéricas (Miller et al., 1961), além de possuirem baixa capacidade de produção de ácido clorídrico e de enzimas proteolíticas necessárias para digerir, principalmente, a fração protéica de origem vegetal dos ingredientes presentes na ração (Shields et al., 1980; Lindemann et al., 1986; Owsley et al. 1986; Pekas, 1991). Assim, o período logo após o desmame dos leitões tem trazido inúmeros problemas relacionados com o tipo e qualidade das matérias-primas empregadas em sua nutrição, o que poderá influenciar o desempenho do animal não só nessa fase, mas também, nas fases seguintes.

Em revisão apresentada por Pluske et al. (1997) sobre as consequências do desmame, os autores citaram que um dos maiores problemas é a agressão às células intestinais caracterizada pelo encurtamento das vilosidades e aumento da profundidade das criptas. Cera et al. (1988) verificaram uma drástica redução na altura das vilosidades do jejuno no $3^{\underline{0}}$ e $7^{\underline{0}}$ dias pós-desmame o que predispõe a uma má absorção, 
multiplicação bacteriana e, conseqüent emente, diarréia, resultando no baixo desempenho característico dessa fase.

A imaturidade relacionada ao sistema imunológico e digestório dos leitões sobre a mudança na morfologia intestinal pode ser acentuada por vários fatores como a idade ao desmame (Cera et al., 1988), a quantidade e composição da dieta ingerida (Pluske et al., 1997; Kelly \& Coutts, 2000), a reação imunológica aos antígenos do farelo de soja nas dietas iniciais ( $\mathrm{Li}$ et al., 1990, 1991), o tempo para as enzimas digestivas se adaptarem e/ou as mudanças no ambiente fisiológico e social (Carrol et al., 1998; Van Djik et al., 2001). Assim, esses fatores influenciam a proliferação e o estado de diferenciação do epitélio, tendo um impacto significativo no desenvolvimento do intestino.

Dentre os nutrientes presentes nas dietas para leitões recém-desmamados, a maior atenção concerne à fonte protéica utilizada, uma vez que essa tem consequência no consumo, ganho de peso, digestibilidade de nutrientes e na atividade das enzimas pancreáticas (Makkink et al., 1994; Peiniau et al., 1996).

Muitos trabalhos já indicaram que o fornecimento de dietas contendo produtos lácteos reduz o desafio nutricional imposto pelo desmame. Isso porque esses produtos são muito digestíveis, devido à presença em grande quantidade da enzima lactase no intestino delgado dos leitões (Pekas, 1991) e, de acordo com Ethridge et al. (1984 a, b), o aumento da digestibilidade da dieta está correlacionado com a diminuição da incidência e severidade da diarréia.

Entretanto, esses produtos lácteos por muitas vezes oneram o custo da ração e nem sempre estão disponíveis. Assim, tentativas têm sido feitas para substituir os produtos do leite por fontes alternativas de proteína, sendo que um ingrediente que vem sendo muito estudado é o plasma sanguíneo, já que a sua composição em aminoácidos e digestibilidade da proteína se assemelham muito à da proteína do leite (Van Dijk et al., 2001). 


\subsection{O plasma sanguíneo na alimentação de suínos}

Uma série de pesquisas foi conduzida nos últimos anos sobre a utilização do plasma sanguíneo na alimentação de leitões recém-desmamados e os resultados foram positivos na grande maioria dos casos. A utilização da proteína do plasma sanguíneo na alimentação de suínos apresentou melhores resultados quando comparada aos produtos da soja (Coffey \& Cromwell, 1995; de Rodas et al., 1995; Angulo \& Cubiló, 1998; Chae et al., 1999; Hartke \& Apgar, 2000), a farinha de peixe selecionada (Koehler et al., 1998) e ao leite desnatado em pó (Gatnau \& Zimmerman, 1990; Hansen et al., 1993; Kats et al., 1994; de Rodas et al., 1995; Smith et al. 1995; Chae et al., 1999; Grinstead et al., 2000). Considerando que a proteína do leite é de alto valor nutricional para leitões, é até surpreendente que na maioria dos experimentos os leitões que receberam plasma sanguíneo na dieta apresentaram melhor desempenho do que os animais que receberam o leite desnatado em pó.

O motivo da superioridade do plasma sanguíneo em relação às outras fontes protéicas ainda não está bem definido. Acredita-se que o melhor desempenho dos suínos que receberam plasma em suas dietas possa estar relacionado com a sua alta palatabilidade (Ermer et al., 1994) ou ainda, devido a sua composição, pois o plasma contém $22,5 \%$ de imunoglobulinas, $48,0 \%$ de albumina e $0,5 \%$ de proteína de baixo peso molecular (Pierce et al., 1995).

Coffey \& Cromwell (1995) propuseram que o plasma sanguíneo pode melhorar o desempenho dos animais após o desmame aumentando a imunocompetência, devido à presença das imunoglobulinas, uma vez que estas podem prevenir os danos causados por patógenos na parede intestinal e manter as propriedades digestivas e absortivas do intestino. Realmente, o melhor desempenho dos animais parece estar relacionado com a imunoglobulina presente no plasma sanguíneo como já demonstrado por Gatnau et al. (1995), Owen et al. (1995), Pierce et al. (1995) e Weaver et al. (1995) que em experimentos comparando cada fração do plasma separadamente oferecida a leitões 
recém-desmamados, concluíram que o fator estimulador do crescimento está presente na fração imunoglobulina.

Entretanto, há uma série de fatores que podem influenciar nas respostas dos animais que receberam plasma sanguíneo em suas dietas. Partindo de uma compilação de dados, Van Dijk et al. (2001) demonstraram que as repostas dos leitões variam em função da composição da dieta controle (tipo de proteína), do "status" de saúde do animal, do nível de inclusão de plasma e do período de oferecimento ao animal.

De acordo com o exposto, nota-se que o ponto diferencial do plasma em relação às outras fontes protéicas normalmente utilizadas no desmame precoce, é a sua riqueza em imunoglobulinas. Assim, é dentro desse contexto, que o ovo integral desidratado aparece como uma opção em potencial, visto que além de ser rico em nutrientes, a sua proteína também possui alta concentração de imunoglobulinas que são essenciais para a sobrevivência de pintos recém-nascidos (Harmon et al., 2001).

\subsection{O ovo como ingrediente de dietas}

\subsubsection{Processamento do ovo}

Nos últimos anos, a indústria de ovos se expandiu muito, principalmente investindo na industrialização do ovo in natura em produto líquido ou desidratado, sendo que a grande parte da utilização desses produtos é feita em indústrias alimentares de panificações e sorvetes (Egg Products, 2000). Para que esses ovos possam ser processados e utilizados na alimentação humana é exigido um rigoroso padrão de qualidade. Assim, os ovos quebrados e trincados produzidos em grandes quantidades anualmente, são descartados, podendo ser aproveitados na alimentação animal.

O mais importante método de produzir ovo em pó como gema, clara e ovo integral é pelo processo denominado spray-dry, onde o produto é atomizado por uma corrente de ar quente e, por causa da grande área de superfície criada pela atomização, a evaporação da água é muito rápida (Bergquist, 1994). A principal consequência desta rápida evaporação é a manutenção da temperatura da gotícula em níveis bem inferiores 
àquelas que causam danos sensíveis nas propriedades essenciais dos produtos do ovo (Aguirre, 1979).

Assim, esse processamento mantém a integridade e funcionalidade dos componentes da proteína, bem como a digestibilidade dos aminoácidos (Campbell et al., 1998). É importante ressaltar que a própria fração imunoglobulina presente no ovo e/ou plasma sofre desnaturação em torno de 56 a $60{ }^{0} \mathrm{C}$, que é bem abaixo da temperatura usada no spray-dry (superior a $100^{\circ} \mathrm{C}$ ). No entanto, essas imunoglobulinas podem manter algum grau de especificidade e se ligarem às bactérias intraluminais, prevenindo a secreção de enterotoxinas (Hansen et al., 1993), como já citado anteriormente.

A desidratação é uma maneira bem sucedida de preservação dos ovos (Bergquist, 1994 e Ohba et al., 1993), sendo que outras vantagens são: ocupar menor espaço no estoque, facilidade de transporte, boa uniformidade e ser livre de microrganismos como a Salmonella. No entanto, o produto final do ovo em pó pode ser afetado por vários fatores como a qualidade do ovo in natura, práticas sanitárias (Bergquist, 1994), condições durante o processamento como temperatura e umidade (Tsai \& Hudson, 1984, 1985; Ranzem et al., 1989; Ohba et al., 1993; Anton \& Gandemer, 1997; Guardiola et al., 1997) e as condições de estocagem (Guardiola et al., 1995, 1997; Huber et al., 1995; Li et al., 1996). Além disso, durante o processamento é necessária a adição de antioxidantes para preservar as características do ovo cru e não permitir a formação de produtos oxidados (Huber et al., 1995; Li et al., 1996).

Dessa forma, para uma segura utilização do ingrediente ovo na formulação de rações, torna-se necessário um processamento adequado, sem prejudicar as características do produto final, principalmente no que diz respeito à desnaturação da fração protéica. Por isso, é importante uma padronização no processamento do ovo em pó para se ter um produto de qualidade que possa ser avaliado para a utilização de maneira adequada na alimentação animal. 


\subsubsection{Valor nutricional e imunológico do ovo}

O ovo é considerado um alimento completo, uma vez que contém todos os nutrientes necessários para produzir um novo organismo. O ovo em pó possui, em média, 47,35\% de proteína bruta (Egg Products, 2000), superior a muitas fontes protéicas utilizadas para leitões, além de ser de alto valor biológico. A proteína do ovo foi considerada durante muito tempo, a proteína padrão pela Organização para Alimentos e Agricultura da Organização Mundial de Saúde (FAO-OMS) (Vieira, 2000). Ainda apresenta valores significativos de outros componentes importantes como: gordura total $(40,95 \%)$, ácidos graxos monoinsaturados $(15,35 \%)$ e polinsaturados $(5,80 \%)$, carboidratos $(4,95 \%)$, além de aminoácidos como metionina $(1,48 \%)$, triptofano $(0,58 \%)$ e, principalmente, lisina (3,40\%) (Egg Products, 2000). Essa riqueza em aminoácidos essenciais aos suínos faz o ovo especialmente valioso para ser utilizado em combinação com os grãos de cereais, os quais são muito pobres nestes aminoácidos.

Entretanto, deve-se alertar para o fato de que, ainda que os alimentos possuam composição química altamente favorável para utilização como ingredientes de ração, podem apresentar propriedades físicas desconhecidas que limitem seu uso como tal (Miyada, 1987).

O ovo cru apresenta alguns fatores antinutricionais como a avidina e o inibidor de tripsina. A avidina é uma proteína presente na albumina que se liga à vitamina biotina formando o complexo avidina-biotina que não é absorvido pelo intestino, causando avitaminose. Esse fator antinutricional pode ser inibido através do cozimento dos ovos, pois a avidina quando é desnaturada pelo calor, não mais se liga à biotina (Lehninger, 1985). Kratzer et al. (1988), testando o ovo em pó, observaram que, quando não se suplementaram as aves com biotina, ocorreram sinais de deficiência dessa vitamina com uma mortalidade de $20 \%$ e que a suplementação de $500 \mu \mathrm{g} / \mathrm{kg}$ foi o suficiente para suprir as necessidades das aves. Os autores concluíram que um mau processamento não inativa completamente a avidina, relevando assim, a importância também dos cuidados no processamento de ingredientes a fim de se obterem produtos de qualidade. 
Também está presente na albumina do ovo, cerca de $10 \%$ de outra proteína chamada ovomucóide, uma das mais importantes substâncias inibidoras de tripsinas (Kato \& Matsuda, 1997), que também são termosensíveis. No entanto, Van Nevel et al. (2000), testando o ovo em pó na alimentação de suínos em crescimento, determinaram $40,0 \mathrm{mg} / \mathrm{g}$ da atividade do inibidor de tripsina neste ingrediente, porém esta quantidade não foi suficiente para causar uma depressão no crescimento dos animais.

Em contraposição, foi observado in vitro que o ovo em pó é um eficiente inibidor da atividade da lectina (ou hemaglutinina), uma proteína encontrada em algumas sementes como tremoço branco (Lupinus albuns) e o grão de soja. Isso porque as lectinas possuem alta afinidade pela ovoalbumina (glicoproteína que constitui $70 \%$ da clara do ovo) (Van Nevel et al., 1998). Assim, em vez das lectinas se ligarem a certos grupos de carboidratos específicos localizados na superfície das células, principalmente nas células do duodeno e jejuno (Nunes et al., 2001), estas se ligariam à ovoalbumina, o que impediria maiores danos à parede intestinal dos animais. Em experimento conduzido por Van Nevel et al. (2000) essa propriedade não foi identificada, uma vez que, quando oferecido para suínos em crescimento, tremoço branco com e sem a adição de ovo em pó, não foram encontradas diferenças no desempenho desses animais. Talvez, em animais recém-desmamados, que são mais susceptíveis aos fatores antinutricionais presentes nos alimentos, essa resposta poderia ser melhor observada.

A característica que realmente torna o ovo muito interessante é a sua fração imunoglobulina, pois, como já citado, no desmame o animal passa por um período de transição, em que deixa de se beneficiar dos anticorpos adquiridos do leite da porca e passa a responder ativamente aos desafios impostos pelo ambiente. Justamente nesta fase é que a nutrição exerce um papel significativo e, sendo a proteína do ovo extremamente rica em imunoglobulinas $(150 \mathrm{mg}$ de gamaglobulina por ovo, de acordo com Harmon et al., 2001), poderá fornecer uma proteção aos leitões desmamados precocemente, assim como demonstrado com o plasma sanguíneo.

Com base nos conteúdos de imunoglobulinas presentes nos ovos, recentemente foi conduzida uma série de estudos utilizando ovos hiperimunizados que são oriundos de poedeiras vacinadas contra patógenos causadores dos problemas entéricos em leitões, 
principalmente a bactéria $E$. coli. Nesses experimentos foi verificado que os leitões, que receberam ovos hiperimunizados em suas dietas, apresentaram um desempenho melhor ou similar àqueles que receberam o plasma sanguíneo (Shipp \& Godfredson-Kisic, 2000; Drew \& Estrada, 2001; Owusu-Asiedu et al., 2001) e a farinha de peixe (Davis et al., 2000). Os autores atribuíram esses resultados às imunoglobulinas presentes no ovo hiperimunizado que agem reduzindo os problemas gastrintestinais, promovendo uma melhora no desempenho dos animais.

Além disso, os animais que não receberam em suas dietas ovo hiperimunizado (controle) apresentaram uma diarréia com alto grau de severidade causando uma mortalidade de 46,5\% (Owusu-Asiedu et al., 2001) a 74\% (Godfredson-Kisic \& Shipp, 2000). Por outro lado os tratamentos com ovo hiperimunizado não apresentaram mortalidade em decorrência da diarréia.

Rizvi et al. (2001) testaram o efeito do ovo hiperimunizado em animais logo após o nascimento, sendo um grupo privado de colostro e outro que recebeu colostro por 24 horas. Além do tratamento com ovo hiperimunizado foi avaliado também o ovo normal (proveniente de poedeiras que não foram vacinadas) e um sucedâneo. Os leitões foram desafiados com E. coli e rotavirus e abatidos grupos às 24, 48, 72 e 96 horas após a infecção. Alimentando com ovo hiperimunizado, $100 \%$ dos animais que receberam colostro e 90,9\% dos animais que não receberam colostro foram eficazes em prevenir a infecção contra $E$ coli. Para o rotavirus não foram detectadas diferenças estatísticas.

Baseado no perfil de nutrientes o ovo aparece como uma boa fonte protéica para leitões recém-desmamados, sendo uma alternativa que pode melhorar a digestibilidade e a qualidade da ração e ainda ser usado profilaticamente para prevenir e reduzir as doenças gastrintestinais, uma vez que a associação destas características aumenta o consumo e maximiza o ganho de peso. 


\subsubsection{O ovo em pó na alimentação de suínos}

Os dados encontrados na literatura sobre a utilização do ovo em pó na alimentação de leitões ainda são bem inconsistentes. Todos os trabalhos envolveram suínos na fase pós-desmame e o nível máximo de inclusão do ovo em pó estudado foi de 12\% (Norin et al, 1998). Trabalho conduzido por Peo Jr. et al. (1969) foi pioneiro em testar o ovo em pó como fonte de proteína oferecida a leitões recém-desmamados, onde não se observaram diferenças quando comparado ao farelo de soja e ao soro de leite.

A maioria das pesquisas indicou um pior resultado dos animais alimentados com ovo em pó em comparação a outros ingredientes protéicos, principalmente o plasma sanguíneo (Nessmith et al., 1996; Norin et al., 1998; Harmon et al., 2000; Jaen et al., 2001; Schmidtt et al., 2001).

Algumas suposições para ais resultados negativos são a falta de dados na literatura sobre o ovo em pó. A própria energia digestível não se encontra disponível em nenhuma tabela de composição química seja brasileira ou estrangeira e nenhum trabalho faz menção a esse valor. Com isso, pode-se considerar que talvez um desbalanço de ordem nutricional possa estar ocorrendo nos trabalhos que utilizam dietas com este ingrediente.

A inclusão de alimentos alternativos nas dietas, principalmente os de origem

animal, podem apresentar variação em sua composição química e muitas vezes uma falta de padronização no processamento, podendo assim, comprometer o desempenho dos animais se não forem considerados adequadamente os níveis de energia e aminoácidos dos mesmos. Dessa forma, torna-se necessária uma contínua avaliação do conteúdo e disponibilidade de nutrientes nesses alimentos, bem como a condução de testes biológicos.

Importante é ressaltar que, como já demonstrado em pesquisas mais recentes envolvendo o ovo em pó, foi considerado além do ingrediente protéico, principalmente, o teor de imunoglobulinas que demonstrou acrescentar um efeito potencial sobre o desempenho dos animais. 


\section{MATERIAL E MÉTODOS}

Os experimentos foram conduzidos no Setor de Suinocultura do Departamento de Produção Animal da Escola Superior de Agricultura "Luiz de Queiroz", da Universidade de São Paulo, em Piracicaba/SP.

O ovo do presente estudo foi preparado a partir do processamento spray-dry, onde o produto resultante é um pó fino de coloração amarela clara, o qual foi incorporado às dietas experimentais. Este produto é comumente denominado de ovo em pó (OP).

\subsection{Instalações e animais}

Em ambos os experimentos os animais foram alojados em uma unidade de creche experimental com 20 gaiolas metálicas suspensas com área de 1,80 $\mathrm{m}^{2}$ cada uma $(1,50 \times 1,20 \mathrm{~m})$. As gaiolas eram providas de comedouro automático, bebedouro tipo chupeta, além de lâmpadas infravermelhas de 250 watts para aquecimento complementar que era ligada sempre que a temperatura era inferior a $28^{0} \mathrm{C}$. A área adjacente ao comedouro era compacta e a sob o bebedouro era metálica e vazada.

Foram utilizados 98 animais das raças Landrace, Large White ou mestiços dessas raças, obtidos no próprio Setor de Suinocultura. 


\subsection{Ensaio de digestibilidade (Experimento I)}

Este experimento foi realizado com oito leitões (quatro machos castrados e quatro fêmeas) com peso médio de $16,0 \pm 1,5 \mathrm{~kg}$, distribuídos de forma homogênea em dois tratamentos com quatro repetições cada, sendo um animal por unidade experimental.

Os tratamentos experimentais consistiram de uma dieta basal, formulada para atender às exigências dos suínos na fase inicial, de acordo com as recomendações de Rostagno et al. (2000) e uma dieta teste, onde o OP substituiu, na base da matéria natural, $30 \%$ da dieta basal. A composição percentual e os valores calculados dos nutrientes da dieta basal são apresentados na Tabela 1.

Empregourse o método da coleta parcial de fezes, utilizando-se o óxido crômico $\left(\mathrm{Cr}_{2} \mathrm{O}_{3}\right)$ como indicador adicionado às dietas experimentais na concentração de $0,5 \%$.

Os animais foram submetidos a um período de adaptação de cinco dias às dietas experimentais, seguidos de cinco dias de coleta de fezes. Durante a fase de adaptação, foi quantificado diariamente o consumo voluntário de cada animal nos diferentes tratamentos (dieta basal e dieta teste) e, o menor consumo serviu de base para a quantidade de ração fornecida durante o período experimental. Dessa forma, cada suíno recebeu uma quantidade diária de ração restrita por unidade de peso metabólico $\left(\mathrm{kg}^{0,75}\right)$, como ilustrado na Tabela A1 do Apêndice.

As dietas foram oferecidas aos animais em duas refeições diárias, sempre às 8:00h e 16:00h, ligeiramente umedecidas para evitar perdas e facilitar a ingestão. As fezes foram coletadas duas vezes ao dia, a partir do sexto dia, diretamente do reto dos animais e logo após o fornecimento da ração. Os suínos receberam água à vontade. 
Tabela 1. Composição percentual e valores calculados da dieta basal do ensaio de digestibilidade. (Experimento I).

\begin{tabular}{|c|c|}
\hline Ingredientes & Dieta basal \\
\hline Milho & 56,20 \\
\hline Farelo de soja & 24,29 \\
\hline Soro de leite & 5,00 \\
\hline Lactose & 5,00 \\
\hline Plasma sanguíneo & 2,00 \\
\hline Açúcar & 4,00 \\
\hline Calcário & 0,63 \\
\hline Fosfato bicálcico & 2,12 \\
\hline Cloreto de colina, $60 \%$ & 0,05 \\
\hline DL-metionina & 0,16 \\
\hline L-Lisina.HCl, $78 \%$ & 0,07 \\
\hline Sal & 0,30 \\
\hline BHT & 0,01 \\
\hline Aromatizante & 0,04 \\
\hline Suplemento vitamínico ${ }^{\mathrm{a}}$ & 0,10 \\
\hline Suplemento mineral $^{\mathrm{b}}$ & 0,10 \\
\hline \multicolumn{2}{|l|}{ Valores calculados: } \\
\hline Proteína bruta, \% & 18,00 \\
\hline Energia digestível, kcal/kg & 3.365 \\
\hline Lisina, $\%$ & 1,00 \\
\hline Fósforo disponível, \% & 0,52 \\
\hline Cálcio, \% & 0,90 \\
\hline
\end{tabular}

${ }^{a}$ Suprindo as seguintes quantidades por kg de ração: vit. A, 8.000 UI; vit $\mathrm{D}_{3}, 1.500 \mathrm{UI}$; vit. E, $18 \mathrm{mg}$; vit. $\mathrm{K}_{3}, 2 \mathrm{mg}$; . vit $\mathrm{B}_{1}, 1,5 \mathrm{mg}$; vit. $\mathrm{B}_{2}, 4 \mathrm{mg}$; vit. $\mathrm{B}_{6} ; 1,5 \mathrm{mg}$; vit. $\mathrm{B}_{12}, 18$ $\mathrm{mg}$; ácido fólico $0,4 \mathrm{mg}$; biotina, $0,1 \mathrm{mg}$; pantotenato de cálcio, $15 \mathrm{mg}$; niacina, $30 \mathrm{mg}$; selênio, $0,12 \mathrm{mg}$.

${ }^{\mathrm{b}}$ Suprindo as seguintes quantidades por kg de ração: manganês, $45 \mathrm{mg}$; cobre, $15 \mathrm{mg}$; zinco, $80 \mathrm{mg}$; ferro, $88 \mathrm{mg}$; iodo, $1 \mathrm{mg}$.

Ao término de cada coleta as fezes foram acondicionadas em sacos plásticos, devidamente identificados para cada parcela e armazenadas em congelador até o período final. Posteriormente, houve o descongelamento à temperatura ambiente e a homogeneização, sendo as amostras reunidas em amostras compostas por animal e colocadas em estufa de circulação forçada à temperatura de $65^{\circ} \mathrm{C}$, por um período de 72 horas. Em seguida, cada amostra foi pesada, moída e enviada ao laboratório para posteriores análises. 


\subsubsection{Análises laboratoriais}

Foram realizadas análises laboratoriais da composição química e energia bruta do OP e das amostras de dietas e fezes. A energia bruta, matéria mineral e matéria seca foram determinadas no laboratório de Bromatologia do Departamento de Produção Animal da ESALQ/USP. As análises foram realizadas em duplicatas de acordo com a metodologia descrita por Silva et al. (1990). Já as análises de proteína bruta e dos aminoácidos e minerais do OP foram determinadas no Laboratório de Bioquímica do ITAL - Instituto de Tecnologia de Alimentos, em Campinas/SP. A proteína bruta e os minerais foram analisados de acordo com a Association of Official Analytical Chemists (AOAC, 1980) e os aminoácidos foram determinados por hidrólise ácida conforme sugerido por Spackman et al. (1958). A concentração de óxido crômico nas dietas e nas fezes foi determinada através da técnica de fluorescência de raios X com dispersão de energia ("energy dispersive X-ray fluorescence", EDXRF), como proposto por Nascimento Filho (1997) e realizada no laboratório de Química Analítica do Centro de Energia Nuclear na Agricultura (CENA/USP)

\subsubsection{Determinação dos coeficientes de digestibilidade aparente dos nutrientes e dos conteúdos de energia e proteína digestíveis do OP}

Com base nos níveis de óxido crômico e composição bruta dos nutrientes nas amostras das dietas e fezes foram calculados os valores médios de digestibilidade da matéria seca, energia, proteína e extrato etéreo das dietas basal e teste sendo utilizadas, de acordo com Serrano (1989), as seguintes fórmulas: 
ND $g$ dieta $=$ NB $g$ dieta $-($ NB $g$ fezes $x$ FI $)$

em que:

- ND g dieta = nutriente digestível por grama de dieta;

- NB g fezes = nutriente bruto por grama de fezes;

- NB g dieta = nutriente bruto por grama de dieta.

- FI = fator de indigestibilidade,

$$
\mathrm{FI}=\frac{\mathrm{g} \mathrm{de} \mathrm{Cr}_{2} \mathrm{O}_{3} / \mathrm{g} \text { de dieta }}{\mathrm{g} \mathrm{de} \mathrm{Cr}_{2} \mathrm{O}_{3} / \mathrm{g} \text { de fezes }}
$$

A partir desta equação, determinaram-se os valores de matéria seca, energia, proteína e extrato etéreo digestíveis do OP (alimento teste), utilizando a equação proposta por Matterson et al. (1965), como exemplificado para o cálculo de energia digestível (ED).

$$
\mathrm{ED} g \mathrm{OP}=\mathrm{ED} g \text { basal }+\frac{(\mathrm{ED} \mathrm{g} \text { teste }-\mathrm{ED} \text { g basal })}{\% \text { de inclusão do ovo } / 100}
$$

em que:

- ED g OP = energia digestível por grama do ovo em pó;

- ED g basal = energia digestível por grama da dieta basal;

- ED g teste = energia digestível por grama da dieta teste.

Com esses resultados, foi possível obter os coeficientes de digestibilidade aparente da matéria seca (CDapMS), energia bruta (CDapEB), proteína bruta (CDapPB) e extrato etéreo (CDapEE) e a energia e proteína digestíveis do OP.

A energia digestível e a composição química do OP forneceram subsídios para a formulação das dietas do Experimento II. 


\subsection{Ensaio de desempenho (Experimento II)}

Este experimento foi realizado com 90 leitões (machos castrados e fêmeas), desmamados aos $24^{ \pm} 2$ dias de idade e peso médio de 5,6 $\pm 0,6 \mathrm{~kg}$. Durante o período de aleitamento, a partir dos sete dias de idade, todos os animais tiveram acesso a uma ração à base de milho, farelo de soja e leite integral em pó e, após o desmame, os leitões foram transferidos imediatamente para as instalações experimentais, dando-se início ao experimento.

Anteriormente ao alojamento dos animais, a sala de creche foi caiada e desinfetada, passando por um vazio sanitário de duas semanas. Diariamente, as instalações eram limpas, o desperdício de ração quantificado e a temperatura ambiente anotada. O experimento foi conduzido durante 28 dias e as temperaturas médias de máxima e mínima registradas foram, respectivamente, 27,9 e $16,2{ }^{0} \mathrm{C}$. No decorrer do experimento, três animais foram descartados devido a problemas sanitários.

O período experimental compreendeu duas fases, sendo uma a pré-inicial (1 a 14 dias pós-desmame) e outra a inicial (15 a 28 dias pós-desmame), onde os tratamentos consistiram de cinco dietas com níveis crescentes de substituição, 0, 25, 50, 75 e 100\% da proteína do plasma sanguíneo (PS) pela proteína do ovo em pó (OP). Para isso, consideraram-se os valores analisados de proteína bruta do PS $(79,5 \%)$ e do OP $(53,5 \%)$, sendo que a somatória desses ingredientes nos diferentes tratamentos forneceu uma contribuição protéica nas dietas de $4,28 \%$ e de $2,14 \%$, respectivamente, para as fases

pré-inicial e inicial. Assim, os níveis de inclusão do OP foram de 0, 2, 4, 6 e $8 \%$ na fase pré-inicial e, na inicial, esses níveis foram reduzidos à metade sendo 0, 1, 2, 3 e 4\%.

As dietas experimentais, todas isonutritivas, foram formuladas para atender as exigências dos suínos em cada fase de criação, baseando-se nas recomendações de Rostagno et al. (2000). Na Tabela 2 (pré-inicial) e Tabela 3 (inicial) são apresentadas à composição percentual e os nutrientes calculados das dietas experimentais. 
Tabela 2. Composição percentual e valores calculados das dietas experimentais fornecidas aos leitões na fase pré-inicial (1 a 14 dias pós-desmame). (Experimento II).

\begin{tabular}{|c|c|c|c|c|c|}
\hline \multirow[b]{2}{*}{ Ingredientes } & \multicolumn{5}{|c|}{ Níveis de substituição protéica do PS pelo OP (\%) } \\
\hline & 0 & 25 & 50 & 75 & 100 \\
\hline Milho & 52,25 & 51,09 & 49,73 & 48,81 & 47,93 \\
\hline Farelo de soja & 21,72 & 21,92 & 22,18 & 22,39 & 22,51 \\
\hline Ovo em pó (OP) & --- & 2,00 & 4,00 & 6,00 & 8,00 \\
\hline Plasma sanguíneo (PS) & 5,38 & 4,04 & 2,69 & 1,35 & --- \\
\hline Soro de leite em pó & 10,00 & 10,00 & 10,00 & 10,00 & 10,00 \\
\hline Lactose & 5,00 & 5,00 & 5,00 & 5,00 & 5,00 \\
\hline Açúcar & 2,00 & 2,00 & 2,00 & 2,00 & 2,00 \\
\hline Calcário & 0,74 & 0,76 & 0,78 & 0,79 & 0,81 \\
\hline Fosfato bicálcico & 1,81 & 1,77 & 1,74 & 1,70 & 1,66 \\
\hline Caulim & --- & 0,31 & 0,78 & 0,89 & 0,96 \\
\hline Óxido de zinco, $78 \%$ & 0,34 & 0,34 & 0,34 & 0,34 & 0,34 \\
\hline L-lisina.HCl, $78 \%$ & 0,22 & 0,23 & 0,25 & 0,27 & 0,29 \\
\hline DL-metionina & 0,08 & 0,07 & 0,06 & 0,05 & 0,04 \\
\hline Cloreto de colina $60 \%$ & 0,05 & 0,05 & 0,05 & 0,05 & 0,05 \\
\hline Sal & 0,20 & 0,20 & 0,20 & 0,20 & 0,20 \\
\hline BHT & 0,01 & 0,01 & 0,01 & 0,01 & 0,01 \\
\hline Suplemento vitamínico ${ }^{\text {a }}$ & 0,10 & 0,10 & 0,10 & 0,10 & 0,10 \\
\hline Suplemento mineral ${ }^{\mathrm{b}}$ & 0,10 & 0,10 & 0,10 & 0,10 & 0,10 \\
\hline \multicolumn{6}{|l|}{ Valores calculados: } \\
\hline Proteína bruta, \% & 20,00 & 20,00 & 20,00 & 20,00 & 20,00 \\
\hline Energia digestível, kcal/kg & 3.385 & 3.385 & 3.385 & 3.385 & 3.385 \\
\hline Fósforo total, \% & 0,67 & 0,67 & 0,67 & 0,67 & 0,67 \\
\hline Cálcio, \% & 0,90 & 0,90 & 0,90 & 0,90 & 0,90 \\
\hline Lisina, \% & 1,35 & 1,35 & 1,35 & 1,35 & 1,35 \\
\hline Metionina, \% & 0,40 & 0,40 & 0,40 & 0,40 & 0,40 \\
\hline Treonina, \% & 0,84 & 0,84 & 0,83 & 0,82 & 0,81 \\
\hline Triptofano, \% & 0,25 & 0,25 & 0,25 & 0,24 & 0,24 \\
\hline \multicolumn{6}{|c|}{$\begin{array}{l}{ }^{a} \text { Suprindo as seguintes quantidades por kg de ração: vit. A, } 8.000 \mathrm{UI} \text {; vit } \mathrm{D}_{3}, 1.500 \mathrm{UI} \text {; } \\
\text { vit. E, } 18 \mathrm{mg} \text {; vit. } \mathrm{K}_{3}, 2 \mathrm{mg} \text {; . vit } \mathrm{B}_{1}, 1,5 \mathrm{mg} ; \text { vit. } \mathrm{B}_{2}, 4 \mathrm{mg} \text {; vit. } \mathrm{B}_{6} ; 1,5 \mathrm{mg} \text {; vit. } \mathrm{B}_{12}, 18 \\
\mathrm{mg} \text {; ácido fólico } 0,4 \mathrm{mg} \text {; biotina, } 0,1 \mathrm{mg} \text {; pantotenato de cálcio, } 15 \mathrm{mg} \text {; niacina, } 30 \mathrm{mg} \text {; } \\
\text { selênio, } 0,12 \mathrm{mg} \text {. }\end{array}$} \\
\hline \multicolumn{6}{|c|}{$\begin{array}{l}\text { ' } \text { Suprindo as seguintes quantidades por kg de ração: manganês, } 45 \text { mg; cobre, } 15 \text { mg; } \\
\text { zinco, } 80 \mathrm{mg} \text {; ferro, } 88 \mathrm{mg} \text {; iodo, } 1 \mathrm{mg} \text {. }\end{array}$} \\
\hline
\end{tabular}


Tabela 3. Composição percentual e valores calculados das dietas experimentais fornecidas aos leitões na fase inicial (15 a 28 dias pós-desmame). (Experimento II).

\begin{tabular}{|c|c|c|c|c|c|}
\hline \multirow[b]{2}{*}{ Ingredientes } & \multicolumn{5}{|c|}{ Níveis de substituição protéica do PS pelo OP (\%) } \\
\hline & 0 & 25 & 50 & 75 & 100 \\
\hline Milho & 58,06 & 57,66 & 57,23 & 56,86 & 56,47 \\
\hline Farelo de soja & 25,54 & 25,63 & 25,70 & 25,78 & 25,85 \\
\hline Ovo em pó (OP) & --- & 1,00 & 2,00 & 3,00 & 4,00 \\
\hline Plasma sanguíneo (PS) & 2,69 & 2,02 & 1,35 & 0,68 & --- \\
\hline Soro de leite em pó & 5,00 & 5,00 & 5,00 & 5,00 & 5,00 \\
\hline Lactose & 3,00 & 3,00 & 3,00 & 3,00 & 3,00 \\
\hline Açúcar & 2,00 & 2,00 & 2,00 & 2,00 & 2,00 \\
\hline Calcário & 0,77 & 0,77 & 0,78 & 0,79 & 0,80 \\
\hline Fosfato bicálcico & 1,89 & 1,87 & 1,84 & 1,83 & 1,81 \\
\hline Óxido de zinco, $78 \%$ & --- & --- & --- & --- & --- \\
\hline L-lisina. $\mathrm{HCl}, 78 \%$ & 0,30 & 0,30 & 0,30 & 0,30 & 0,30 \\
\hline DL-metionina & 0,15 & 0,16 & 0,17 & 0,18 & 0,19 \\
\hline Cloreto de colina, $60 \%$ & 0,04 & 0,03 & 0,03 & 0,02 & 0,02 \\
\hline Sal & 0,05 & 0,05 & 0,05 & 0,05 & 0,05 \\
\hline $\mathrm{BHT}$ & 0,30 & 0,30 & 0,30 & 0,30 & 0,30 \\
\hline Suplemento vitamínico a & 0,01 & 0,01 & 0,01 & 0,01 & 0,01 \\
\hline Suplemento mineral ${ }^{\mathrm{b}}$ & 0,10 & 0,10 & 0,10 & 0,10 & 0,10 \\
\hline \multicolumn{6}{|l|}{ Valores calculados: } \\
\hline Proteína bruta, \% & 19,50 & 19,50 & 19,50 & 19,50 & 19,50 \\
\hline Energia digestível, $\mathrm{kcal} / \mathrm{kg}$ & 3.360 & 3.370 & 3.375 & 3.380 & 3.390 \\
\hline Fósforo total, \% & 0,68 & 0,68 & 0,68 & 0,68 & 0,68 \\
\hline Cálcio, \% & 0,90 & 0,90 & 0,90 & 0,90 & 0,90 \\
\hline Lisina, \% & 1,20 & 1,20 & 1,20 & 1,20 & 1,20 \\
\hline Metionina, \% & 0,35 & 0,35 & 0,35 & 0,35 & 0,35 \\
\hline Treonina, \% & 0,79 & 0,79 & 0,78 & 0,78 & 0,77 \\
\hline Triptofano, $\%$ & 0,24 & 0,24 & 0,24 & 0,24 & 0,23 \\
\hline
\end{tabular}

${ }^{a}$ Suprindo as seguintes quantidades por kg de ração: vit. A, 8.000 UI; vit $\mathrm{D}_{3}, 1.500 \mathrm{UI}$; vit. $\mathrm{E}, 18 \mathrm{mg}$; vit. $\mathrm{K}_{3}, 2 \mathrm{mg}$; vit $\mathrm{B}_{1}, 1,5 \mathrm{mg}$; vit. $\mathrm{B}_{2}, 4 \mathrm{mg}$; vit. $\mathrm{B}_{6} ; 1,5 \mathrm{mg}$; vit. $\mathrm{B}_{12}, 18$ $\mathrm{mg}$; ácido fólico $0,4 \mathrm{mg}$; biotina, $0,1 \mathrm{mg}$; pantotenato de cálcio, $15 \mathrm{mg}$; niacina, $30 \mathrm{mg}$; selênio, $0,12 \mathrm{mg}$.

${ }^{\mathrm{b}}$ Suprindo as seguintes quantidades por kg de ração: manganês, $45 \mathrm{mg}$; cobre, $15 \mathrm{mg}$; zinco, $80 \mathrm{mg}$; ferro, $88 \mathrm{mg}$; iodo, $1 \mathrm{mg}$. 
O experimento foi realizado com nove repetições por tratamento, utilizando um delineamento em blocos completos casualizados, onde cada repetição foi composta por dois animais, totalizando 45 unidades experimentais. Para a formação dos blocos consideraram-se o peso inicial e a leitegada de origem. Foram realizadas repetições no tempo de acordo com a disponibilidade de animais e instalações para o experimento.

Os leitões receberam ração e água à vontade durante todo o período experimental. Para a avaliação do desempenho dos animais (ganho diário de peso, consumo diário de ração e conversão alimentar) para as fases pré-inicial (1 a 14 dias) e inicial (15 a 28 dias) e período total (1 a 28 dias), foram realizadas pesagens individuais e os registros de consumo de ração para cada parcela. A média de cada parcela representou a unidade experimental. Também foram analisados o peso inicial, peso aos 14 dias e peso aos 28 dias dos animais.

Ao final da última pesagem os leitões foram submetidos a um período de jejum de 12 horas e, posteriormente, receberam, durante 30 minutos, uma alimentação à vontade e mais um jejum de cinco horas para a retirada de amostras de sangue através da veia cava anterior.

O sangue de cada animal foi coletado em seringas de $10 \mathrm{~mL}$. Para as análises dos componentes plasmáticos (uréia, proteína total, albumina, globulina, triglicérides e colesterol) foi utilizado um tubo SST (serum separator tube) de $4 \mathrm{~mL}$. Para as análises dos componentes sanguíneos (hematócrito e hemoglobina) foi utilizado um tubo de 3 $\mathrm{mL}$ contendo 0,21 $\mathrm{mL}$ de EDTA (ácido etileno-diamino-tetracético). As amostras foram imediatamente enviadas ao Laboratório de Análises Clínicas Previlab Ltda., em Piracicaba, SP.

Os dados de desempenho obtidos em cada fase e os dados plasmáticos e sanguíneos foram submetidos à análise de variância PROC GLM do SAS (Statistical Analysis System, 1996). Além disso, os graus de liberdade dos tratamentos foram decompostos em seus componentes individuais de regressão, pelos polinômios ortogonais. 


\section{RESULTADOS E DISCUSSÃO}

\subsection{Ensaio de digestibilidade (Experimento I).}

Os resultados da composição química completa e o valor de energia bruta do ovo em pó (OP) são apresentados na Tabela 4.

Tabela 4. Composição química e valor energético do ovo em pó, expresso na matéria natural (Experimento I).

\begin{tabular}{lc}
\hline Matéria seca, \% & 92,70 \\
Proteína bruta, \% & 53,56 \\
Aminoácidos essenciais: & \\
Leucina, \% & 4,77 \\
Lisina, \% & 4,26 \\
Valina, \% & 3,41 \\
Arginina, \% & 3,34 \\
Fenilalanina, \% & 3,18 \\
Isoleucina, \% & 2,77 \\
Treonina, \% & 2,69 \\
Metionina, \% & 2,53 \\
Histidina, \% & 1,56 \\
Energia bruta, kcal/kg & 5.897 \\
Extrato etéreo, \% & 22,15 \\
Matéria mineral, \% & 5,74 \\
Minerais: & \\
Cálcio, \% & 0,26 \\
Fósforo, \% & 0,54 \\
Sódio, \% & 0,24 \\
Potássio, \% & 0,27 \\
Magnésio, ppm & 600 \\
Zinco, ppm & 40 \\
Ferro, ppm & 40 \\
Cobre, ppm & 3 \\
\hline
\end{tabular}


Em relação ao conteúdo de proteína bruta do OP, o valor de 53,56\%, encontrado no presente trabalho, está dentro da faixa dos valores publicados na literatura que variam de 46,00\% a 56,60\% (Cotteril et al., 1978; Owen et al., 1993; Van Nevel et al., 2000; Hannas et al., 2001; Harmon et al., 2001). Portanto, observa-se que o OP pode apresentar uma variação relativamente ampla no conteúdo de proteína bruta, possivelmente em função do tamanho de ovos e/ou perda das frações gema ou clara de ovos quebrados.

Comparando com os valores protéicos de outras fontes utilizadas em dietas complexas para leitões em fase de creche, verifica-se que o conteúdo de proteína bruta do OP foi superior ao do leite em pó desnatado $(33,65 \%)$, mas inferior ao plasma sanguíneo (69,70\%) (Rostagno et al., 2000). Esse dado é importante, admitindo que a maioria das dietas formuladas para suínos se baseia no conteúdo de proteína bruta do ingrediente, além de a proteína do ovo apresentar um elevado valor biológico, normalmente referido como a de valor equivalente a 100 para o ser humano.

O OP apresentou valores elevados de aminoácidos essenciais aos suínos como lisina $(4,26 \%)$, treonina $(2,69 \%)$ e metionina $(2,53 \%)$, sendo superior aos determinados por Harmon et al. (2001) de 3,72 e 2,23\%, respectivamente para lisina e treonina. Com base em seu conteúdo de aminoácidos, o OP apresentou concentrações iguais ou superiores de lisina, treonina e metionina (primeiro, segundo e quarto aminoácidos limitantes aos suínos, respectivamente) em comparação a outras fontes protéicas ricas em aminoácidos como o farelo de soja, leite desnatado em pó e farinha de peixe (Rostagno et al., 2000).

O valor da energia bruta de $5.897 \mathrm{kcal} / \mathrm{kg}$ do OP foi inferior ao determinado por Hannas et al. (2001) de $6.201 \mathrm{kcal} / \mathrm{kg}$. Essa diferença possivelmente pode ser explicada pelo menor teor de extrato etéreo $(22,15 \%)$ encontrado no presente trabalho em comparação àquele $(32,71 \%)$ apresentado por Hannas et al. (2001). É importante salientar, que na literatura são encontrados valores de extrato etéreo variando de 27,20\% a 44,30\% (Harmon et al., 2001; Van Nevel et al., 2000; Owen et al., 1993 e Cotteril et al., 1978), o que demonstra a grande variabilidade do OP em relação a esse nutriente. 
Como consequência da referida variação na composição, pode-se admitir a diferença em valores de energia bruta desse ingrediente.

Quanto à fração inorgânica, os valores de $0,26 \%$ de cálcio e $0,27 \%$ de potássio foram inferiores aos encontrados tanto por Hannas et al. (2001) (0,32 e 0,48\%, respectivamente) como por Harmon et al. (2001) (0,36 e 0,61\%, respectivamente). Notase um valor expressivo de $0,54 \%$ de fósforo, sendo, no entanto, inferior a $0,76 \%$, encontrado por Harmon et al. (2001). Um valor que também chama a atenção é o baixo conteúdo de ferro (40 ppm) encontrado para o OP neste trabalho, contrariando ao valor de 120 ppm determinado por Harmon et al. (2001) e contrapondo Vieira (2001) que afirmou ser o ovo uma fonte rica nesse micromineral.

Essas diferenças tanto na concentração de nutrientes como no valor energético do OP podem ser explicadas pela falta de padronização no processamento a que o ovo é submetido. Bertol \& Ludke (1999) afirmaram que um processamento inadequado pode causar uma alteração na disponibilidade dos nutrientes, variando assim, o valor nutricional do alimento. Além disso, essas diferenças podem estar associadas à origem do ingrediente, uma vez que são processados ovos de diversas granjas e a alimentação das poedeiras pode alterar o perfil de nutrientes do ovo (Egg Products, 2000).

$\mathrm{Na}$ Tabela 5, são apresentados os coeficientes de digestibilidade aparente da matéria seca (CDapMS), energia bruta (CDapEB), proteína bruta (CDapPB), extrato etéreo (CDapEE), e os valores de energia digestível (ED) e proteína digestível (PD) do OP.

Tabela 5. Valores dos coeficientes de digestibilidade aparente (CDap) de nutrientes e a energia e proteína digestíveis do ovo em pó. (Experimento I).

CDap da Matéria seca, $\%$

CDap da Energia bruta, \%

CDap da Proteína bruta , \%

CDap do Extrato etéreo, \%

Energia digestível, kcal/kg

Proteína digestível, \%
87,20

80,75

82,00

70,55

5.140

43,90 
A determinação dos coeficientes de digestibilidade é de grande importância, pois mesmo que a composição dos nutrientes de um ingrediente seja favorável, não quer dizer que reflita na disponibilidade biológica dos mesmos.

De maneira geral, os coeficientes de digestibilidade aparente de nutrientes determinados para o OP apresentaram-se elevados quando comparados a valores encontrados na literatura brasileira para outros ingredientes protéicos como farinha de peixe (Battisti et al., 1985), farinha de carne e ossos (Serrano, 1989), leite desnatado em pó (Moreira et al., 1994) e plasma desidratado (Pupa et al., 1999).

É importante ressaltar que a digestibilidade das várias frações do alimento pode ser influenciada pela idade e peso dos animais (Fialho et al., 1982 a, b). O ensaio de digestibilidade do presente estudo foi realizado com leitões mais velhos e pesados que os anteriormente referidos na literatura, nos quais foram utilizados animais recémdesmamados. Além disso, a digestibilidade dos nutrientes de alimentos processados depende, também, da própria composição do alimento, do tipo de processamento, do tempo e temperatura de aquecimento e do nível de inclusão do alimento na ração, entre outros (Moreira et al., 1994).

Assim como o OP, os produtos de origem animal geralmente apresentam uma alta digestibilidade de seus nutrientes, principalmente da proteína, pois as enzimas digestivas têm uma especificidade para aminoácidos essenciais nos quais os produtos animais são ricos (Vieira, 2000). De acordo com Nelson \& Cox (2000) a enzima tripsina age somente sobre as ligações peptídicas envolvendo o grupamento carboxila da arginina e da lisina, que são aminoácidos essenciais aos suínos.

$\mathrm{A}$ ED do OP de $5.140 \mathrm{kcal} / \mathrm{kg}$ determinada nesse trabalho foi inferior àquela encontrada por Hannas et al. (2001) de $5.390 \mathrm{kcal} / \mathrm{kg}$, enquanto a PD foi superior $(43,90 \%$ vs 40,27\%). Recentemente, Harmon et al. (2001) determinaram o valor de energia metabolizável do OP para leitões recém-desmamados como sendo de 4.700 $\mathrm{kcal} / \mathrm{kg}$.

No geral, o valor determinado de energia digestível do OP foi superior aos valores de todos os outros alimentos utilizados como fonte de energia para suínos, com 
exceção de óleos e gorduras. Harmon et al. (2001) destacaram ser esta uma importante característica do OP, chegando a apresentar $37 \%$ mais energia do que o milho, principal fonte energética para os suínos.

Há fortes indicações de que o processamento por spray-dry, a que fôra submetido o ovo, foi efetuado nas condições de temperatura e umidade adequadas, o que manteve íntegra as características do produto final, sem prejudicar a digestibilidade de seus nutrientes. Dessa forma, as elevadas concentrações de proteína bruta e energia bruta, aliada ao correto processamento, resultaram em altos valores de energia e proteína digestíveis do OP. Esses resultados demonstraram que o OP pode ser utilizado não só como fonte protéica de qualidade, mas também contribuir com o valor energético na alimentação de leitões em fase de creche.

\subsection{Ensaio de desempenho (Experimento II)}

\subsubsection{Características de desempenho}

Os valores médios dos tratamentos para as variáveis ganho diário de peso (GDP), consumo diário de ração (CDR) e conversão alimentar (CA) referentes às fases pré-inicial (1 a 14 dias), inicial (15 a 28 dias) e período total (1 a 28 dias) são apresentados nas Tabelas 6, 7 e 8, respectivamente. Os valores originais dos dados de desempenho são apresentados nas Tabelas A2, A3 e A4, no Apêndice. 
Tabela 6. Valores médios dos tratamentos para peso inicial (PI), ganho diário de peso (GDP), consumo diário de ração (CDR), conversão alimentar (CA) e peso aos 14 dias (P14) dos leitões, referentes à fase pré-inicial (1 a 14 dias pósdesmame) (Experimento II).

\begin{tabular}{llllllr}
\hline & \multicolumn{7}{c}{ Níveis de substituição protéica do PS pelo OP, \% ${ }^{\text {a }}$} & \\
& 0 & 25 & 50 & 75 & 100 & CV $^{\text {a }}$ \\
\hline PI, kg & 5,57 & 5,58 & 5,60 & 5,68 & 5,64 & 2,4 \\
GDP, kg & 0,175 & 0,185 & 0,190 & 0,161 & 0,150 & 22,3 \\
CDR, kg & 0,313 & 0,313 & 0,338 & 0,311 & 0,311 & 12,8 \\
CA & 1,83 & 1,78 & 1,82 & 2,07 & 2,13 & 18,2 \\
P14, kg & 8,00 & 8,40 & 8,26 & 8,00 & 7,85 & 8,1 \\
\hline
\end{tabular}

${ }^{\mathrm{a}}$ Coeficiente de variação, \%

Tabela 7. Valores médios dos tratamentos para ganho diário de peso (GDP), consumo diário de ração (CDR), conversão alimentar (CA) e peso aos 28 dias (P28) dos leitões, referentes à fase inicial (15 a 28 dias pós-desmame) (Experimento II).

\begin{tabular}{lcccccc}
\hline \multicolumn{7}{c}{ Níveis de substituição protéica do PS pelo OP, \% } \\
& 0 & 25 & 50 & 75 & 100 & $\mathrm{CV}^{\mathrm{a}}$ \\
\hline $\mathrm{GDP}, \mathrm{kg}^{\mathrm{a}}$ & 0,576 & 0,531 & 0,546 & 0,491 & 0,446 & 10,9 \\
$\mathrm{CDR}, \mathrm{kg}^{\mathrm{b}}$ & 0,890 & 0,840 & 0,838 & 0,770 & 0,722 & 10,2 \\
$\mathrm{CA}$ & 1,55 & 1,60 & 1,54 & 1,57 & 1,63 & 6,0 \\
$\mathrm{P} 28, \mathrm{~kg}^{\mathrm{b}}$ & 16,08 & 15,81 & 15,91 & 14,88 & 14,52 & 7,7 \\
\hline
\end{tabular}

${ }^{\mathrm{a}}$ Efeito linear $(\mathrm{P}<0,01)$

${ }^{\mathrm{b}}$ Coeficiente de variação, \%

Tabela 8. Valores médios dos tratamentos para ganho diário de peso (GDP), consumo diário de ração (CDR) e conversão alimentar (CA) dos leitões, referentes ao período total (1 a 28 dias pós-desmame) (Experimento II).

\begin{tabular}{llllllr}
\hline \multicolumn{7}{c}{ Níveis de substituição protéica do PS pelo OP, \% } \\
& 0 & 25 & 50 & 75 & 100 & $\mathrm{CV}^{\mathrm{a}}$ \\
\hline $\mathrm{GDP}, \mathrm{kg}^{\mathrm{a}}$ & 0,375 & 0,357 & 0,368 & 0,326 & 0,298 & 11,2 \\
$\mathrm{CDR}, \mathrm{kg}^{\mathrm{b}}$ & 0,615 & 0,581 & 0,608 & 0,555 & 0,528 & 8,8 \\
$\mathrm{CA}$ & 1,65 & 1,65 & 1,66 & 1,71 & 1,80 & 7,2 \\
\hline
\end{tabular}

${ }^{\mathrm{a}}$ Efeito linear $(\mathrm{P}<0,01)$

${ }^{\mathrm{b}}$ Coeficiente de variação, \% 
De acordo com os resultados, observa-se que os níveis de inclusão da proteína do $\mathrm{OP}$ em substituição à proteína do PS não influenciaram $(\mathrm{P}>0,05)$ as variáveis de desempenho na fase pré-inicial de 1 a 14 dias pós-desmame. Entretanto, é importante que se observem os coeficientes de variação $(\mathrm{CV})$ que se mostraram elevados para essas variáveis. Isso significa que houve um aumento de fatores não controlados (erro experimental) o que pode dificultar a detecção das diferenças entre os tratamentos aplicados.

Observando os dados, mesmo sem diferenças significativas $(\mathrm{P}>0,05)$, verifica-se que a completa substituição da proteína do PS pela proteína do OP resultou no menor GDP e pior CA, sendo que o melhor resultado alcançado foi com $50 \%$ de contribuição protéica de cada ingrediente.

Estes resultados concordam com os relatos de Jaen et al. (2001) e Harmon et al. (2000) que encontraram uma melhor resposta para a combinação de PS com OP do que para apenas o OP. Na realidade, Jaen et al. (2001) verificaram que a substituição de 50\% do PS por OP resultou em melhor GDP (+ $24 \mathrm{~g})$ e CDR (+ $52 \mathrm{~g})$ em relação a $100 \%$ de substituição. Já Harmon et al. (2000) ofereceram a leitões desmamados aos 16 dias de idade, quatro combinações de proteína do OP e do PS durante um período de 24 dias pós-desmame e encontraram maiores GDP e CDR para os animais que receberam as dietas com 0 e $33 \%$ de proteína de OP em comparação aos animais que receberam as dietas com 66 e $100 \%$ de proteína de OP.

Nessmith et al. (1996) ofereceram a leitões uma combinação, com base no conteúdo de lisina, de 5,0\% de PS $+4,95 \%$ de OP e 2,5\% de PS $+9,9 \%$ de OP e observaram apenas um CDR inferior quando a inclusão de OP foi maior. Já quando o PS foi combinado com outras fontes protéicas como proteína concentrada de soja e farinha de peixe, os animais que receberam estas combinações apresentaram um GDP e CA melhores que os animais que receberam a combinação com OP.

Mesmo com o OP promovendo um pior desempenho dos animais é interessante relatar que Nessmith et al. (1996) e Harmon et al. (2000) não observaram diferenças entre as variáveis de desempenho dos animais quando estes passaram a receber uma 
dieta basal após a alimentação com OP, verificando então, que os animais não foram prejudicados a ponto de comprometer seus desempenhos nas fases posteriores.

Comparando o OP com outras fontes protéicas, Owen et al. (1993) concluíram que $6 \%$ de inclusão do OP em substituição ao farelo de soja e 3\% de inclusão do OP em substituição ao PS não afetaram o GDP dos leitões. Entretanto, com $6 \%$ de inclusão do OP em substituição ao PS houve uma redução significativa (- 35 g) para essa mesma variável.

Por outro lado, Norin et al. (1998) não detectaram diferenças entre o desempenho dos leitões que receberam dietas com 6 ou 12\% de inclusão de OP, embora ambas tenham promovido menor GDP dos leitões, quando comparadas com a dieta padrão, baseada em farelo de soja, PS e soro de leite.

Schimidt et al. (2001) testaram a substituição do PS pelo OP e pela clara em pó nas dietas de leitões desmamados aos 17 dias e verificaram um GDP superior para o PS em 72 g em relação ao OP e em 47 g em relação a clara em pó e para o CDR essa superioridade foi de 45 e $19 \mathrm{~g}$, respectivamente. Observa-se que o OP promoveu um pior desempenho dos animais quando comparado às outras duas fontes protéicas.

Nesta fase pré-inicial, de 1 a 14 dias do período experimental, a variável CA apresentou uma tendência $(\mathrm{P}<0,10)$ de piora linear $(\mathrm{CA}=1,74836+0,003554 \mathrm{X})$ na medida em que os níveis de substituição protéica do PS pelo OP aumentaram. Esse resultado pode ser explicado pela maior variação entre os valores do GDP, pois o CDR foi semelhante entre os tratamentos. Owen et al. (1993) verificaram que leitões recebendo 3 ou $6 \%$ de OP obtiveram uma pior CA em relação ao grupo controle (com PS). No entanto, Harmon et al. (2000) observaram que o OP pode substituir completamente o PS em dietas de leitões, sem afetar a CA.

Para a fase inicial, correspondente ao período de 15 a 28 dias pós-desmame, foram observadas diferenças estatísticas significativas $(\mathrm{P}<0,01)$. Vale lembrar que durante a fase pré-inicial os níveis de inclusão do OP nas dietas foram de 0, 2, 4, 6 e 8\%, respectivamente para os tratamentos $0,25,50,75$ e $100 \%$ e, nesta fase inicial, os níveis 
foram reduzidos à metade, sendo $0,1,2,3$ e $4 \%$ de inclusão de OP para os respectivos tratamentos.

Assim, observaram-se reduções lineares $(\mathrm{P}<0,01)$ do GDP $(\mathrm{GDP}=0,57784$ 0,00129X), CDR (CDR = 0,89302-0,00162X) e para a variável peso aos 28 dias (P28) (P28 = 16,27333 - 0,01622X), onde X é a \% de substituição da proteína do PS pela proteína do OP. Estas respostas são ilustradas nas Figuras 1, 2 e 3, respectivamente. Para a variável CA não foi detectada diferença significativa $(\mathrm{P}>0,05)$. Nota-se, de acordo com o comportamento linear, que para cada $1 \%$ de inclusão do OP, os animais reduziram em 1,29 g o GDP e em 1,62 g o CDR.

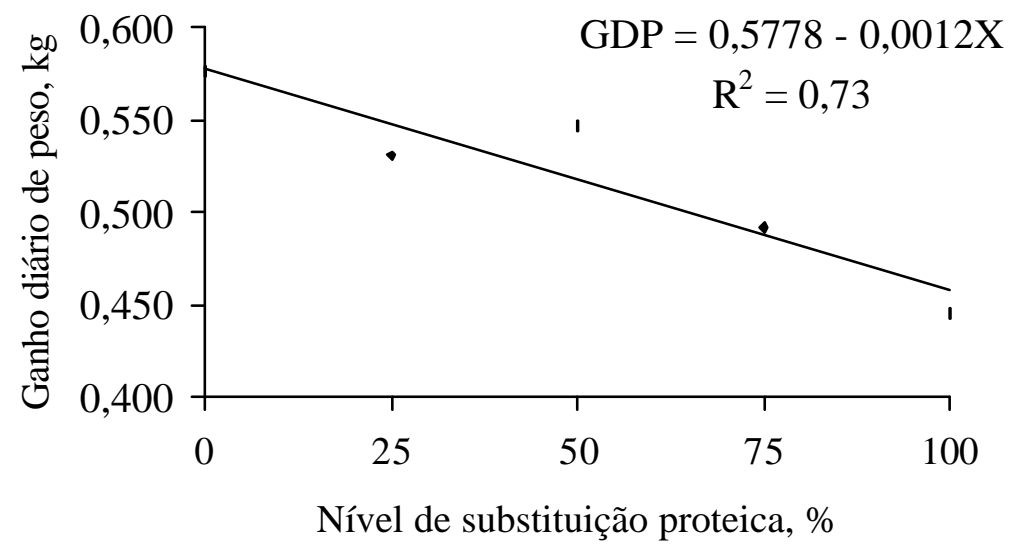

Figura 1 - Efeito da substituição protéica do plasma sanguíneo pelo ovo em pó sobre o ganho diário de peso (GDP) de leitões durante a fase inicial de 15 a 28 dias pós-desmame. (Experimento II). 


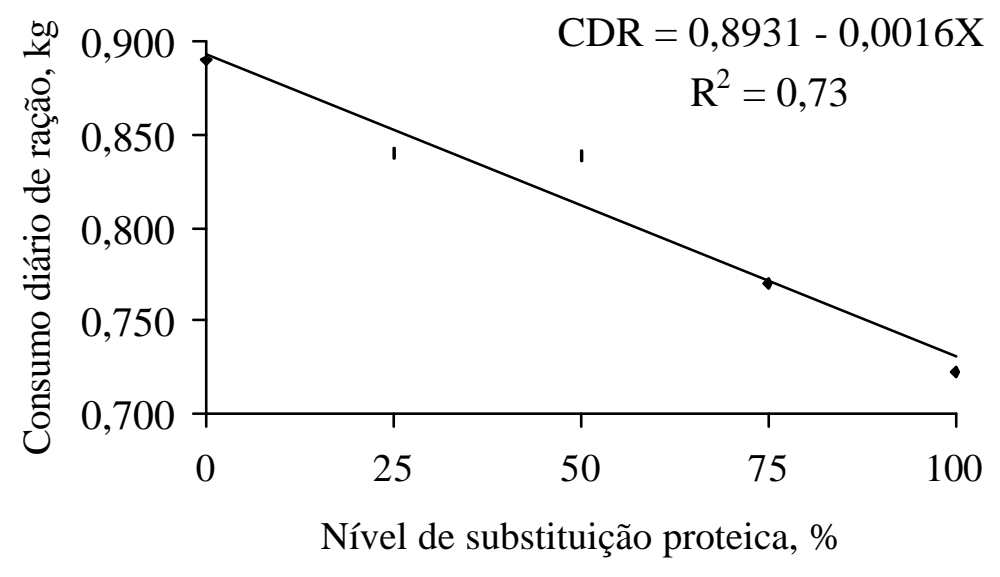

Figura 2 - Efeito da substituição protéica do plasma sanguíneo pelo ovo em pó sobre o consumo diário de ração (CDR) de leitões durante a fase inicial de 15 a 28 dias pós-desmame. (Experimento II).

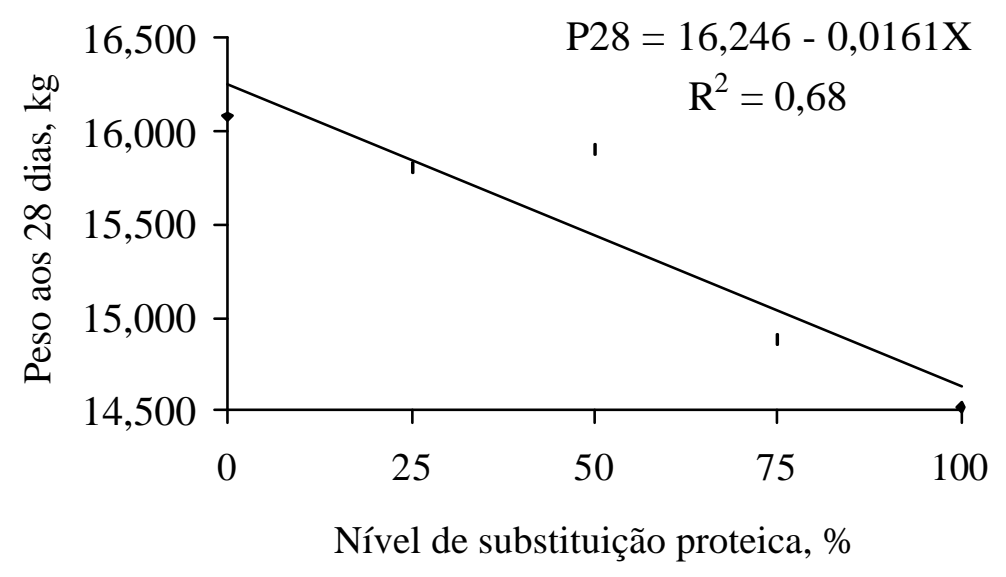

Figura 3 - Efeito da substituição protéica do plasma sanguíneo pelo ovo em pó sobre o peso aos 28 dias (P28) dos leitões. (Experimento II). 
Para o período total (1 a 28 dias) foram também observadas reduções lineares $(\mathrm{P}<0,01)$ para as variáveis GDP $(\mathrm{GDP}=0,38191-0,00074 \mathrm{X})$ e $\mathrm{CDR}(\mathrm{CDR}=0,61729$ - 0,00079X) à medida que se aumentava a \% de substituição da proteína do PS pela proteína do OP. Estas respostas são ilustradas nas Figuras 4 e 5, respectivamente. Entretanto, para a CA não foi observado efeito significativo $(\mathrm{P}>0,05)$, mas sim uma forte tendência $(\mathrm{P}<0,06)$ de piora linear $(\mathrm{CA}=1,61977+0,00146 \mathrm{X})$ com a inclusão de OP.

Os trabalhos na literatura indicam que o desempenho dos animais nas fases posteriores ao desmame tem uma forte relação com os resultados obtidos em função das dietas oferecidas nos primeiros 14 dias pós-desmame (de Rodas et al., 1995; Hansen et al., 1993; Mahan \& Lepine, 1991; Cera et al., 1988) e não com o fornecimento de dietas complexas após esse período.

Murad (1991) testou cinco níveis de substituição (0, 12,5, 25,0, 37,5 e 50\%) da proteína do farelo de soja pela proteína da farinha de ovos (ovos secos em estufa de ventilação forçada) em leitões de 15 a $30 \mathrm{~kg}$ de peso vivo e não encontrou diferenças no desempenho dos animais. Da mesma forma, Van Nevel et al. (2000) ofereceram para suínos em crescimento seis dietas com níveis crescentes de inclusão de tremoço branco $(0,15$ ou $30 \%)$ com e sem a adição de $5 \%$ de OP e não verificaram diferenças no desempenho dos animais entre as dietas com e sem o ovo. Essa leguminosa é rica no fator antinutricional lectina ou hemaglutinina e, uma propriedade do OP determinada in vitro é a capacidade de se ligar a essas lectinas, impedindo que causem danos à mucosa intestinal. Assim, animais em crescimento que já possuem o sistema digestório e imunológico bem desenvolvidos são menos susceptíveis aos fatores antinutricionais presentes nos alimentos e também à qualidade dos ingredientes, diferente de leitões recém-desmamados. 


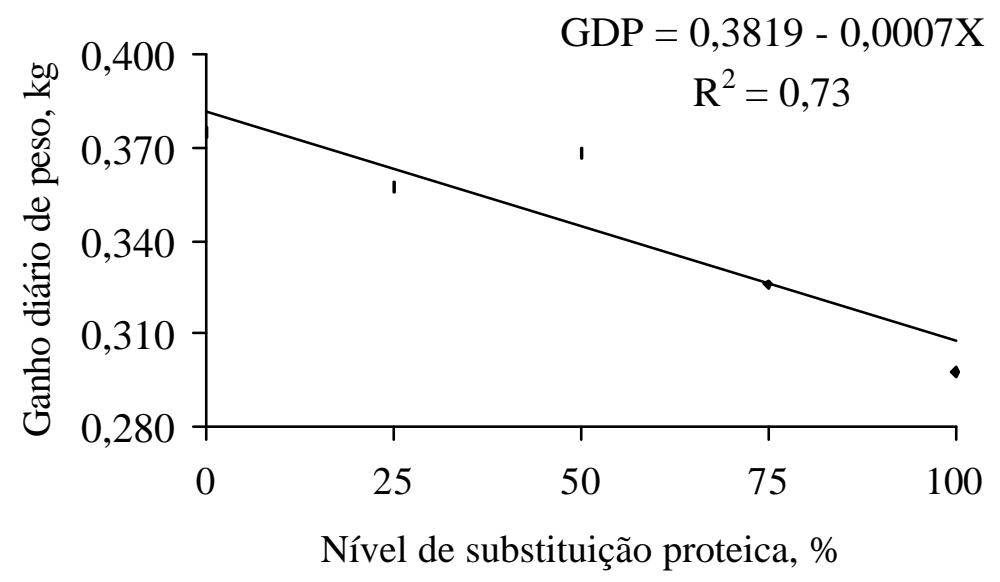

Figura 4 - Efeito da substituição protéica do plasma sanguíneo pelo ovo em pó sobre o ganho diário de peso (GDP) em leitões durante o período total (1 a 28 dias pós-desmame). (Experimento II).

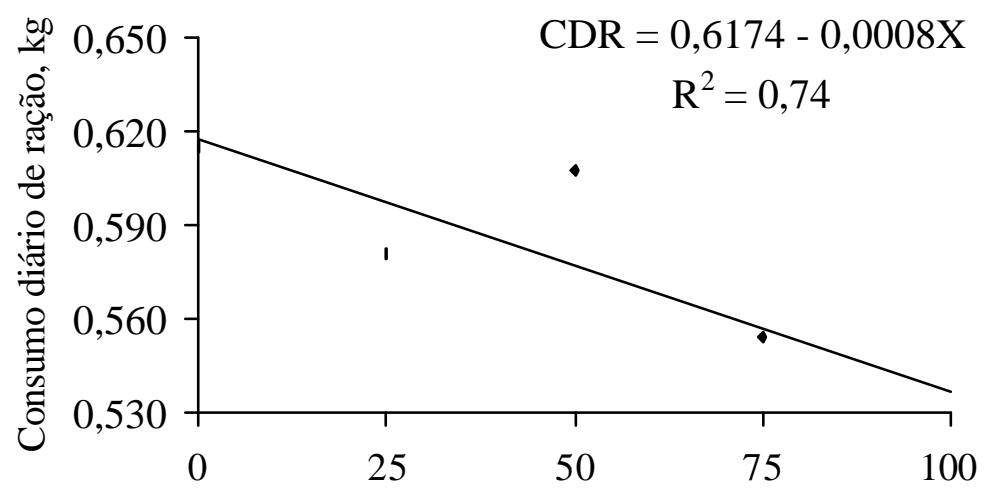

Nível de substituição proteica, \%

Figura 5 - Efeito da substituição protéica do plasma sanguíneo pelo ovo em pó sobre o consumo diário de ração (CDR) de leitões durante o período total (1 a 28 dias pós-desmame). (Experimento II). 
Dessa forma, possivelmente, as diferenças entre os tratamentos encontradas para a segunda fase de criação (15 a 28 dias) e período total (1 a 28 dias) podem ser um reflexo de que na primeira fase (1 a 14 dias) os animais foram prejudicados ao receber a proteína do OP em substituição à proteína do PS. Esse fato é melhor identificado quando se observam as diferenças significativas ocorridas no período total para as variáveis GDP, CDR e, principalmente, peso aos 28 dias, onde houve uma diferença de 1,56 kg a mais para os animais que receberam a dieta sem OP (tratamento 0\%) em relação aos animais que receberam a dieta cuja fonte PS foi totalmente substituída pelo OP (tratamento $100 \%)$.

Existem alguns fatores que podem explicar o pior desempenho dos animais que receberam maiores proporções de OP em suas dietas e, um deles, é a pior palatabilidade do OP em relação ao PS. Em grande parte dos dados encontrados na literatura, o prejuízo no desempenho dos leitões que receberam o OP em suas dietas foi atribuído a um menor consumo de ração (Nessmith et al., 1996; Norin et al., 1998; Harmon et al., 2000; Jaen et al., 2000; Schmidtt et al., 2001). Em contrapartida, Ermer et al. (1994) testaram a preferência de leitões que podiam escolher entre a dieta contendo PS ou leite desnatado em pó e o consumo foi maior em 200 g/dia para a dieta com PS. Resultados semelhantes foram encontrados por Hansen et al. (1993) e Butolo et al. (1999).

Assim, a pior palatabilidade apresentada pelo OP associada com a melhor palatabilidade do PS, pode ter promovido um menor consumo de ração e, consequentemente, menor ganho de peso dos animais que receberam maiores quantidades de OP em suas dietas, refletindo no desempenho inferior observado.

Outra possibilidade poderia ser atribuída ao conteúdo de glicose presente no ovo, uma vez que, durante o processamento por spray-dry do ovo avaliado no presente trabalho, não houve a remoção dessa glicose. De acordo com Aguirre et al. (1979) e Berquist (1994) se nem toda a glicose for removida, pode ocorrer a interação glicoseproteína (reação de Maillard), onde a ação do calor e a presença da água aceleram essa 
reação. No processo de desidratação do ovo o ar é aquecido a temperaturas entre 121 a $232{ }^{0} \mathrm{C}$, com a umidade podendo variar de 4 a $10 \%$ (Berquist, 1994). Como o grupo $\mathrm{NH}_{2}$ do carbono épsilon $(\Sigma)$ do aminoácido lisina (primeiro limitante para suínos) está envolvido nesta reação, o resultado é um decréscimo do valor biológico da proteína e, consequentemente, um pior desempenho dos animais alimentados com OP. Por outro lado, os mesmos autores comentaram que nem os pré-tratamentos, como a pasteurização $\left(60{ }^{0} \mathrm{C}\right)$ e a secagem em si, se corretamente executados, parecem diminuir o valor biológico. Concordando com esta afirmação, Jaen et al. (2001) observaram que o OP pasteurizado ou não pasteurizado, substituindo 50 e $100 \%$ de PS, não afetaram o GDP (P $>0,01)$ de leitões desmamados aos 20 dias de idade.

Uma terceira possibilidade que poderia explicar o pior desempenho dos animais que receberam maiores proporções de OP em suas dietas é a deficiência da vitamina biotina causada pela glicoproteína avidina presente na albumina do ovo, resultado, talvez, de um subprocessamento. Cunha et al. (1946) verificaram que suínos em crescimento que receberam uma dieta contendo $30 \%$ de clara desidratada apresentaram os sintomas típicos de deficiência de biotina (alopecia, rachadura nos cascos, etc), além de diminuição no ganho de peso e piora da conversão alimentar. Mast et al. (1984) e Kratzer et al. (1988) utilizando, respectivamente, 20 e 43\% de ovo em pó nas dietas de frangos de corte, também observaram redução no crescimento das aves e atribuíram a queda no desempenho à presença da avidina.

Entretanto, é pouco provável que o pior desempenho de leitões alimentados com OP seja em virtude da presença da avidina pois, no presente estudo, a inclusão máxima desse ingrediente foi de apenas $8 \%$ na primeira fase e de $4 \%$ na segunda fase de criação. Para humanos é preciso haver o consumo de 24 ovos crus por dia para a avidina se complexar com a biotina a ponto de causar problemas (American Egg Board, 2002). 


\subsubsection{Componentes plasmáticos e sanguíneos}

Os valores médios dos tratamentos para as variáveis dos componentes plasmáticos (uréia, proteína total, albumina, globulina, relação albumina/globulina, triglicérides e colesterol) e dos componentes sanguíneos (hemoglobina e hematócrito), determinados em amostras colhidas no final do experimento, são apresentados na Tabela 9. Os dados originais para os componentes plasmáticos e sanguíneos são apresentados na Tabela A5, no Apêndice.

Tabela 9. Valores médios dos tratamentos para os componentes plasmáticos e sanguíneos. (Experimento II).

\begin{tabular}{lrrrrrr}
\hline & \multicolumn{7}{c}{ Níveis de substituição protéica do PS pelo OP, \% } \\
& \multicolumn{1}{c}{0} & \multicolumn{1}{c}{25} & \multicolumn{1}{c}{50} & 75 & 100 & CV $^{\mathrm{a}}$ \\
\hline Componentes plasmáticos: & & & & & & \\
$\quad$ Uréia, mg/dl & 33,94 & 29,00 & 27,67 & 24,11 & 30,06 & 18,14 \\
Proteína total, g/dl & 5,53 & 5,61 & 5,51 & 4,79 & 5,33 & 4,07 \\
Albumina, g/dl & 3,71 & 3,72 & 3,67 & 3,22 & 3,66 & 5,99 \\
Globulina, g/dl & 1,82 & 1,89 & 1,84 & 1,57 & 1,67 & 13,08 \\
Relação albumina/globulina & 2,12 & 2,06 & 2,03 & 1,89 & 2,29 & 15,44 \\
Triglicérides, mg/dl & 28,94 & 32,94 & 26,83 & 30,33 & 36,89 & 25,69 \\
Colesterol, mg/dl & 91,72 & 87,17 & 91,67 & 74,06 & 87,89 & 11,49 \\
Componentes sanguíneos: & & & & & & \\
Hemoglobina, g/dl & 11,93 & 12,92 & 12,01 & 10,26 & 12,09 & 18,54 \\
Hematócrito, \% & 38,19 & 35,10 & 38,04 & 32,07 & 37,89 & 8,44 \\
\hline a Coeficiente de variação, \% & \multicolumn{7}{c}{}
\end{tabular}

Os níveis de inclusão da proteína do OP em substituição à proteína do PS não influenciaram $(\mathrm{P}>0,05)$ nenhuma das variáveis dos componentes plasmáticos. Entretanto, para a componente uréia (UR) no plasma dos leitões, observou-se uma forte tendência $(\mathrm{P}<0,07)$ de redução linear $(\mathrm{UR}=31,48889$ - 0,47422X), à medida que se aumentavam a inclusão de OP nas dietas. Os valores determinados são similares aos valores obtidos por Miyada (1987) e Preciado (1990) para leitões em recria, porém superiores aos encontrados por Etheridge et al. (1984a). 
Danielson et al. (1989) trabalhando com suínos adultos alimentados com 10,6\% de ge ma em pó durante 56 dias, observaram um aumento significativo $(\mathrm{P}<0,05)$ na uréia no dia 28 que se manteve até o dia 56. Discordando desse resultado, no presente trabalho foi encontrado um nível mais alto de uréia no plasma dos animais que receberam o tratamento sem OP em relação ao daqueles recebendo PS e OP combinados, sendo o tratamento com $75 \%$ de inclusão da proteína do OP, o menor nível de uréia determinado.

A uréia é o produto final do catabolismo dos aminoácidos dos mamíferos e é produzida, de maneira geral, ou quando a dieta é rica em proteína e os aminoácidos ingeridos excedem a necessidade corporal para a síntese protéica ou durante o jejum quando as proteínas celulares são usadas como fonte de energia para o corpo (Nelson e Cox, 2000). Na nutrição animal, outro motivo é quando a dieta é inadequada em algum dos aminoácidos essenciais e a síntese de proteína não ocorre em velocidade igual a quando esse aminoácido está disponível em níveis adequados (Penz Jr. e Viola, 1998). Dessa forma, há um aumento da concentração de uréia no plasma devido a um imbalanço de aminoácidos (Brow e Cline, 1974; Coma et al., 1995) ou devido ao consumo de uma proteína de má qualidade (Brow e Cline, 1974).

Assim, a redução de uréia observada mo tratamentos com maior inclusão de OP, pode refletir em uma utilização mais eficiente do nitrogênio total e um melhor equilíbrio dos aminoácidos desse ingrediente, indicando ser uma proteína de alto valor biológico. Contudo, essa afirmação é questionável, pois um melhor aproveitamento dos aminoácidos deveria resultar em um melhor desempenho dos animais, o que não foi comprovado no presente trabalho para o período total. Norin et al. (1998) relataram que a concentração de uréia no plasma indica que as diferenças no desempenho dos animais estão relacionadas com as diferenças na disponibilidade da proteína e/ou qualidade, concluindo que uma menor concentração de uréia resultaria em melhor desempenho.

Os próprios trabalhos na literatura são conflitantes em estabelecer se o nível de uréia no plasma é um bom indicativo das exigências dos suínos em relação ao nutriente proteína/aminoácido, sendo observados resultados positivos (Chen et al., 1995; Coma et 
al., 1995) e negativos (Lima et al., 1990; Donzele et al., 1992; Fontes et al., 2000; Hannas et al., 2000).

Quanto ao componente proteína total (PT), os valores determinados no presente trabalho estão dentro dos valores encontrados para suínos nessa idade (Miller et al., 1962; Etherid ge et al., 1984; Miyada, 1987; Preciado, 1990), mas inferior ao valor determinado para suínos adultos (Danielson et al., 1989). Para esta variável também houve uma tendência $(\mathrm{P}<0,08)$ de redução linear $(\mathrm{PT}=5,59555-0,03079 \mathrm{X})$ com o aumento dos níveis de inclusão da proteína do $\mathrm{OP}$ em detrimento à proteína do PS.

A adição de OP nas dietas não influenciou $(\mathrm{P}>0,05)$ os componentes plasmáticos albumina, globulina e a relação albumina/globulina. Os valores do componente plasmático albumina dos leitões foi semelhante aos valores determinados por Berto (1985), Miyada (1987) e Preciado (1990), porém os valores do componente globulina foram inferiores aos determinados por estes mesmos autores. Assim, a relação albumina/globulina do presente estudo, quando comparada com a dos trabalhos referidos anteriormente, foi superior.

Berto (1985) encontrou uma redução linear do componente proteína total e albumina nos suínos que receberam níveis crescentes de levedura seca em suas dietas. A causa desta resposta, segundo o autor, pode ter sido uma consequência da redução da proteína verdadeira da dieta, visto que uma significativa fração do nitrogênio da levedura não compõe os aminoácidos. Diferente da levedura, mais de $90 \%$ do nitrogênio do ovo é composta por aminoácidos, entretanto, como já citado, um processamento inadequado do ovo pode acarretar na indisponibilidade de alguns aminoácidos, o que levaria a uma diminuição em seu valor biológico.

Uma moderada deficiência de proteína ou de um único aminoácido da dieta, pode provocar uma queda no conteúdo de proteínas séricas, principalmente devido à redução da albumina (Pond \& Maner, 1974, citado por Miyada, 1987). Segundo esses mesmos autores, a concentração plasmática dessas variáveis pode ser critério para avaliar a nutrição protéica de suínos. 
Dessa forma, os resultados obtidos para os componentes uréia e proteínas globulares (proteína total, albumina, globulina e relação albumina/globulina) são contraditórios, pois o aumento da inclusão do OP causou uma redução nos níveis de uréia, supondo um melhor balanço da proteína e aproveitamento desse ingrediente pelos animais. Entretanto, concomitantemente, houve também a redução das proteínas globulares, o que é um indicativo de uma menor disponibilidade de aminoácidos para a síntese das mesmas. Considerando o pior desempenho dos animais que receberam maiores concentrações de OP em suas dietas, é provável que os componentes plasmáticos proteínas globulares reflitam melhor sobre a nutrição protéica desses animais.

Mesmo com um alto CV $(25,69 \%)$ foi possível observar uma tendência ( $\mathrm{P}<$ $0,08)$ de aumento linear do conteúdo de triglicérides $(\mathrm{TG}=28,5333+0,85076 \mathrm{X})$ à medida em que se aumentava a inclusão de OP. Esses valores determinados estão bem abaixo dos encontrados na literatura para suínos em crescimento (Miyada, 1987; Preciado, 1990) e para suínos adultos (Danielson et al., 1989).

De acordo com Miyada (1987), há fortes evidências de que o nível de triglicérides no plasma seja influenciado pelo nível de energia da ração. Dessa forma, com as rações sendo isocalóricas, não deve haver diferenças significativas entre os tratamentos. Entretanto, a concentração de triglicérides do plasma de leitões que receberam a dieta só com OP (tratamento 100\%) foi 27,5\% superior ao daqueles que receberam a dieta sem OP (tratamento 0\%). Por outro lado, Danielson et al. (1989) observaram que o nível de triglicérides em suínos adultos se manteve similar durante 56 dias em que foram submetidos a uma dieta com 10,6\% de gema em pó.

O nível de colesterol se manteve similar entre os tratamentos, sendo estes valores bem próximos àqueles determinados por Danielson et al. (1989) para suínos adultos, porém inferiores àqueles determinados por Miyada (1987) para suínos em recria. Contudo, suínos adultos alimentados com dietas contendo 10,6\% de gema em pó, durante 56 dias, apresentaram um aumento significativo (43\%) do colesterol no dia 28 , mantendo-se elevado até o dia 56 (Danielson et al., 1989). 
O nível de colesterol no plasma dos animais pode ser controlado pelo estado nutricional, teores dietéticos de gordura e fatores hormonais (Mendonça Jr., 1996), sendo que um organismo possuidor de controle enzimático normal, mediante altas ingestões de colesterol, promove a redução de sua síntese orgânica, mantendo os níveis de colesterol estáveis (Naber, 1990). Assim, o aumento do colesterol no plasma está mais relacionado com as quantidades de energia e gordura saturada ingeridas do que da própria ingestão do colesterol em si (Mendonça Jr., 1996).

A genética do animal também pode influenciar no nível de colesterol plasmático. Pond \& Mersmann. (1990) demonstraram que suínos geneticamente obesos apresentam maiores concentrações de colesterol no plasma do que aqueles geneticamente magros. Porém, quando oferecida uma dieta com 10,5\% de gordura contendo 0 ou $0,5 \%$ de colesterol, os suínos magros apresentaram maiores alterações no colesterol plasmático do que os obesos.

Quanto aos componentes sanguíneos, não houve qualquer influência $(P>0,05)$ da substituição da proteína do PS pela proteína do OP sobre a concentração de hemoglobina e hematócrito. Os valores determinados para estes componentes estão discretamente superiores àqueles apresentados por Etheridge et al. (1984a), Miyada (1987) e Preciado (1990).

De acordo com Pond \& Maner (1974), citados por Miyada (1987), o nível de hemoglobina e hematócrito são indicadores do estado nutricional dos suínos quanto ao nutriente ferro. Como o OP, do presente trabalho, apresentou um baixo conteúdo de ferro, determinado previamente no Experimento I, justificam-se os valores similares desses componentes sanguíneos entre os tratamentos. Também, há indicações de que o hematócrito possa estar relacionado ao nível de lisina da ração (Miyada, 1987). Dessa forma, considerando que ambos ingredientes (OP e PS) que variaram nas dietas são fontes ricas em lisina, e, todas as dietas foram isolisínicas, os níveis de hematócrito permaneceram estáveis. 


\section{CONCLUSÕES}

O ovo em pó é um alimento que apresenta uma composição química com alto conteúdo de proteína bruta $(53,56 \%)$ e energia bruta $(5.897 \mathrm{kcal} / \mathrm{kg})$ e coeficientes de digestibilidade aparente da matéria seca, energia bruta, proteína bruta e extrato etéreo de, respectivamente, $87,20,80,75,82,00,70,55 \%$, proporcionando valores de $43,91 \%$ de proteína digestível e $5.159 \mathrm{kcal} / \mathrm{kg}$ de energia digestível. Baseado nestes resultados, fica evidenciado que o ovo em pó pode ser utilizado tanto como fonte protéica como energética para leitões em fase de creche.

Esse ingrediente pôde substituir completamente o plasma sanguíneo sem afetar o desempenho dos animais na fase pré-inicial de 1 a 14 dias pós-desmame, sendo que, quando sua proteína foi combinada em 50\% com a proteína do plasma sanguíneo, observou-se o melhor resultado. Entretanto, para a fase de 15 a 28 dias, a combinação em diferentes proporções, ou, a substituição protéica completa do plasma sanguíneo pelo ovo em pó, prejudicou o desempenho dos animais, refletindo assim, em um pior desempenho no período total (1 a 28 dias).

Os componentes sanguíneos e plasmáticos dos leitões não foram alterados em função do fornecimento de dietas contendo diferentes proporções de proteína do ovo em pó em substituição à proteína do plasma sanguíneo. 


\section{REFERÊNCIAS BIBLIOGRÁFICAS}

AGUIRRE, J.M.; TRAVAGLINI, D. A.; SILVEIRA, E. T. F. Desidratação de ovos. Boletim do Instituto de Tecnologia de Alimentos, v.16, n.3, p. 261-287, jul/dez. 1979.

AMERICAN EGG BOARD. http://www.aeb.org (07 abr. de 2002).

ANGULO, E.; CUBILÓ, D. Effect of different dietary concentrations of spray-dried porcine plasma and a modified soyprotein product on the growth performance of piglets weaned at $6 \mathrm{~kg}$ body weight. Animal Feed Science and Technology, v. 72, p. 71-79, 1998.

ANTON, M.; GANDEMER, G. Composition, solubility and emulsifying properties of granules and plasma of egg yolk. Journal of Food Science, v. 62, n.3, p. 484-487, 1997.

ASSOCIATION OF OFFICIAL ANALYTICAL CHEMISTS. Official methods of analysis. 13. ed. Washington, 1980. 1025p.

BAtTISTI, J. A.; PEREIRA, J. A. A.; COSTA, P. M. A. et al. Composição química e valores energéticos de alguns alimentos pra suínos com diferentes idades. Revista da Sociedade Brasileira de Zootecnia, v. 14, n. 2, p. 141-151, 1985. 
BERTO, D. A. Levedura seca de destilaria de álcool de cana-de-açúcar (Saccharomyces spp.) na alimentação de leitões em recria. Piracicaba, 1985. 133p. Dissertação (Mestrado) Escola Superior de Agricultura Luiz de Queiroz, Universidade São Paulo.

BERQUIST, D. H. Egg dehyration. In: STADELMAN, W. J.; COTTERILL, O. J. Egg science and technology. New York: Food Products Press, 1994. cap. 14, p. 335-376.

BERTOL, T. M.; LUDKE, J. V. Determinação dos valores de energia e do balanço de nitrogênio de alguns alimentos para leitões na fase inicial. Revista da Sociedade Brasileira de Zootecnia, v. 28, n. 6, p. 1279-1287, 1999.

BROWN, J. A.; CLINE, T. R. Urea excretion in the pig: an indicator of protein quality and amino acid requeriments. Journal of Nutrition, v.104, p. 542-551, 1974.

BUTOLO, E. A. F.; MIYADA, V. S.; PACKER, I. U. et. al. Uso de plasma suíno desidratado por Spray-dryer na dieta de leitões desmamados precocemente. Revista Brasileira de Zootecnia, v. 28, n. 3, p. 326-333, 1999.

CAMPBELL, J. M.; WEAVER, E. M.; RUSSELL, L. E. et al. The use of plasma and blood cells in swine feeds. In:. SIMPÓSIO SOBRE NUTRIÇÃO E MANEJO DE LEITÕES, Campinas, 1998. Anais. Campinas: CBNA, 1998. p. 18-32.

CARROLL, J. A.; VEUM, T. L.; MATTERI, R. L. Endocrine responses to weaning and changes in post-weaning diet in the young pig. Domestic Animal Endocrinology, v. 15, n. 3, p. 183-194, 1998.

CERA, K. R.; MAHAN, D. C.; CROSS, R. F. Effect of age, weaning and postweaning diet on small intestinal growth and jejunal morphology in young swine. Journal of Animal Science, v. 66, n. 2, p. 574-584, 1988. 
CHAE, B. J.; HAN, I. K.; KIM, J. H. et al. Effects of dietary protein sources on ileal digestibility and growth performance for early-weaned pigs. Livestock Production Science, v. 58, p. 45-54, 1999.

CHEN, H. Y.; MILLER, P. S.; LEWIS, A. J. Changes in plasma urea concentration can be used to determine protein requeriments of two populations of pigs with different protein accretion rates. Journal of Animal Science, v. 73, p. 2631-2639, 1995.

COFFEY, R. D.; CROMWELL, G. L. The impact of environment and antimicrobial agents on the growth response of early-weaned pigs to spray-dried porcine plasma. Journal of Animal Science, v. 73, p. 2532-2539, 1995.

COMA, J.; CARRION, D.; ZIMMERMAN, D. R. Use of plasma urea nitrogen as a rapid response criterion to determine the lysine requeriment of pigs. Journal of Animal Science, v. 73, p. 472-481, 1995.

COTTERILL, O. J.; GLAUERT, J.; FRONING, W. Nutriente composition of commercially spray-dried egg products. Poultry Science, v. 57, p. 439-442, 1978.

CUNHA, T. J.; LINDLEY, D. C.; ENSMINGER, M. E. Biotin deficiency syndrome in pigs fed desiccated egg white. Journal of Animal Science, v. 5, n. 2, p. 219-225, 1946.

DAVIS, M. E.; BROWN D. C.; MAXWELL, C. V. et al. Potential for as extruded multiple protein complex (Profound ${ }^{\mathrm{TM}}$ ) as a replacement for fish meal in early weaned pig diets. www.asas.org/jas/00meet/part18.pdf (15 fev. 2002).

DANIELSON, A. D.; PEO Jr., E. R.; SHAHANI, K. M. Effect of feeding dried egg yolk on serum constituents in adult boars. Nutrition Reports International, v. 40, p. 227-231, 1989. 
De RODAS, B. Z.; SOHN, K. S.; MAXWELL, C. V. et al. Plasma protein for pigs weaned at 19 to 24 days of age. Effect on performance and plasma insulin-like growth factor-I, growth hormone, insulin and glucose concentrations. Journal of Animal Science, v. 76, p. 3657-3665, 1995.

DONZELE, J. L.; COSTA, P. M. A.; ROSTAGNO, H. S. et al. Níveis de proteína bruta para suínos de 5 a 15 kg. Revista da Sociedade Brasileira de Zootecnia, v.21, p. 1077-1083, 1992.

DREW, M. D.; ESTRADA, A. E. The effect of feeding spray-dried porcine plasma and egg immunoglobulins with anti-bacterial or anti-somatostatin specificities on the performance of weaned pigs. http://www.asas.org/jas/jointabs/iaafsc11.pdf (15 fev. 2002).

EGG PRODUCTS .http://www.aeb.org/proc/egg_products.html (10 fev. de 2000).

ERMER, P. M.; MILLER, P. S.; LEWIS, J. A. Diet preference and meal patterns of wealing pigs offered diets containing either spray-dried porcine plasma or dried skim milk. Journal of Animal Science, v. 72, n.6, p. 1548-1554, 1994.

ETHERIDGE, R. D.; SEERLEY, R. W.; WYATT, R. D. The effect of diet on performance, digestibility, blood composition and intestinal microflora of weaned pigs. Journal of Animal Science, v. 58, n. 6, p. 1396-1402, 1984a.

ETHERIDGE, R. D.; SEERLEY, R. W.; HUBER, T. L. The effect of diet on fecal moisture, osmolarity of fecal extracts, products of bacterial fermentation and loss of minerals in feces of weaned pigs. Journal of Animal Science, v. 58, n. 6, p. 1403-1411, 1984b. 
FIAlHO, E. T.; BELlAVER, C.; GOMES, P., C. et al. Composição química e valores de digestibilidade de alimentos para suínos em diferentes pesos. Revista da Sociedade Brasileira de Zootecnia, v. 11, n. 2, p. 262-280, 1982a.

FIALHO, E. T.; FERREIRA, A. S.; GOMES, P., C. et al. Valores de composição química, balanço energético e protéico de alguns alimentos determinados com suínos de deferentes pesos. Revista da Sociedade Brasileira de Zootecnia, v. 11, n. 3, p. 558-577, 1982b.

FONTES, D. O.; DONZELE, J. L.; FERREIRA, A. S. et al. Níveis de lisina para leitoas selecionadas geneticamente para deposição de carne magra, dos 60 aos $95 \mathrm{~kg}$. Revista da Sociedade Brasileira de Zootecnia, v. 29, n. 3, p. 784-793, 2000.

GATNAU, R.; ZIMMERMAN, D. R. Spray-dried porcine plasma (SDPP) as a source of protein for weanling pigs. Journal of Animal Science, v. 68, supp. 1, p.374, 1990.

GATNAU, R.; CAIN, C.; DREW, M. et al. Mode of action of spray-dried porcine plasma in weanling pigs. Journal of Animal Science, v.73, supp. 1, p.82, 1995.

GODFREDSON-KISIC, J. A.; SHIPP, T. Evaluation of PROTIMAX during various phases of rearing on piglet performance. http://www.asas.org/jas/00meet/part18.pdf (15 fev. 2002).

GUARDIOLA, F.; CODONY, R.; MANICH, A. et al. Stability of polyunsaturated fatty acids in egg powder processed and stored under various conditions. Journal of Agriculture and Food Chemistry, v. 43, p. 2254-2259, 1995. 
GUARDIOLA, F.; CODONY, R.; RAFECAS, M. et al. Oxysterol formation in spray - dried egg processed and stored under various conditions: prevention and relationship with other quality parameters. Journal of Agriculture and Food Chemistry, v. 45, p. 2229-2243, 1997.

GRINSTEAD, G. S.; GOODBAND, R. D.; DRITZ, M. D. et al. Effects of a whey protein product and spray-dried animal plasma on growth performance of wealing pigs. Journal of Animal Science, v. 78, p. 647-657, 2000.

HANNAS, M. I.; KRONKA, R. N.; THOMÁZ, M. C. et al. Composição química, valores de energia e proteína digestíveis do plasma suíno e ovo desidratado por spray-dried para suínos. In: REUNIÃO ANUAL DA SOCIEDADE BRASILEIRA DE ZOOTECNIA, 38., Piracicaba, 2001. Resumos. Piracicaba: ESALQ, 2001. p. 851-852.

HANNAS, M. I.; OLIVEIRA, R. F. M.; DONZELE, J., L. et al. Proteína bruta para suínos machos castrados mantidos em ambiente de conforto térmico dos 15 aos $30 \mathrm{~kg}$. Revista da Sociedade Brasileira de Zootecnia, v.29, n.2, p. 476-484, 2000.

HANSEN, J. A.; NELSSEN, J. L.; GOODBAND, R. D.; et al. Evaluation of animal protein supplements in diets of early-weaned pigs. Journal of Animal Science, v. 71, n. 7, p. 1853-1862, 1993.

HARMON, B. G.; LATOUR, M. A.; DURST, J. Spray dried eggs as an ingredient in diets for SEW pigs. http://www.ansc.purdue.edu/swine/swineday/sday00/psd03-2000.html (30 nov. 2000).

HARMON, B. G.; LATOUR, M. A.; NORBERG, S. The use of spray dried eggs as an ingredient in diets for infantile pigs and broilers. http://www.ansc.purdue.edu/swine/swineday/sday01/sday01/10.pdf (13 jan. 2002). 
HARTKE, J.; APGAR, G. The effect of spray-dried animal plasma addition to nursery diets varyung in soybean meal concentration. http://www.asas.org/jas/00meet/part18.pdf (15 fev. 2002).

HUBER, K. C.; PIKE, O. A.; HUBER, C. S. Antioxidant inhibition of cholesterol oxidation in a spray-dried food system during accelerated storage. Journal of Food Science, v. 60, n. 5, p. 909-912, 1995.

JAEN, J. F.; MAXWELL, C. V.; JOHNSON, Z. B. et al. Potential for egg protein as a protein source for phase 1 nursey diets. http://www.asas.org/jas/jointabs/iaafs48.pdf (15 fev. 2002).

KATO, Y.; MATSUDA, T. Glycation of proteinous inhibitors: loss in trypsin inhibitory activity by the blocking of arginine and lysine residues at their reactive sites. Journal of Agriculture and Food Chemistry, v.45, p. 3826-3831, 1997.

KATZ, L. J.; NELSSEN, J. L.; TOKACH, M. D. et al. The effect of spray-dried animal porcine plasma on growth performance in the early-weaned pigs. Journal of Animal Science, v. 72, p. 2075-2081, 1994.

KELLY, D.; COUTTS, A. G. P. Development of digestive and immunological function in neonates: role of early nutrition. Livestock Production Science, v. 66, p. 161-167, 2000.

KOEHLER, D. D.; SHURSON, G. C.; WHITNEY, M. H. Effect of spray-dried porcine solubles, with and without spray dried porcine plasma on growth performance of weaned pigs. Journal Animal Science, v.76, suppl. 1, p.180, 1998. 
KRATZER, F. H.; KNOLLMAN, K.; EARL, L. et al. Availability to chicks of biotin from dried egg products. Journal of Nutrition, v. 118, p. 604-608, 1988.

LEHNINGER, A. L. Princípios de bioquímica. São Paulo: Sarvier, 1985. cap. 24, p. 537564: Nutrição humana.

LI, D. F.; NELSEN, J. L.; REDDY, P. G. et al. Transient hypersensitivity to soybean meal in the early weaned pig. Journal of Animal Science, v. 68, n. 6, p. 1790-1799, 1990.

LI, D. F.; NELSEN, J. L.; REDDY, P. G. et al. Measuring suitabillity of soybean products for early weaned pigs with immunological criteria. Journal of Animal Science, v. 69, n. 8, p. 3299-3307, 1991.

LI, S., X.; CHERIAN, G.; SIM, J. S. Cholesterol oxidation in egg yolk powder during storage and heating as affected by dietary and tocopherol. Journal of Food Science, v. 61, n. 4, p. 721-725, 1996.

LIMA, J. A. F.; PEREIRA, J. A. A.; COSTA, P. M. A. et al. Efeito da idade de desmama sobre as exigências de proteína bruta para leitões na fase pré-inicial (desmama a $15 \mathrm{~kg}$ PV). Revista da Sociedade Brasileira de Zootecnia, v. 19, n. 5, p.363-369, 1990.

LINDEMANN, M. D.; CORNELIUS, S. G.; KANDELGY, S. M. et al. Effect of age, weaning and diet on digestive enzyme levels in the piglets. Journal of Animal Science, v. 62, n. 5, p. 1298-1307, 1986.

MAHAN, D. C.; LEPINE, A. J. Effect of pig weaning weight and associated nursery feeding programs on subsequent performance to 105 kilograms body weight. Journal of Animal Science, v. 69, n. 4, p. 1370-1378, 1991. 
MAKKINK, C. A.; BERNTSEN, P. J.; Op Den KAMP, B. M. et al. Gastric protein breakdown and pancreatic enzyme activities in response to two different dietary protein sources in newly weaned pigs. Journal of Animal Science, v. 72, p. 2843-2850, 1994.

MAST, M. G.; LEACH, R. M.; MACNEIL, J. H. Performance, composition and quality of broiler chickens fed dried whole eggs. Poultry Science, v. 63, p. 1940-1945, 1984.

MATTERSON, L. D.; POTTER, L. M.; STUTZ, M. W. et al. Research reports. Stors: The University of Connecticut Agricultural Experiment Station, 1965. 11p.

MENDONÇA Jr, C. X. Colesterol no Ovo - Possibilidades de sua Redução. In:. SIMPÓSIO LATINO - AMERICANO DE NUTRIÇÃO DE SUÍNOS E AVES, Campinas, 1996. Anais. Campinas: CBNA, 1996. p. 87-117.

MILLER, E. R.; ULREY, D. E.; ACKERMAN, I. et al. Swine hematology from birth to maturity. I. Serum proteins. Journal of Animal Science, v. 20, n. 1, p. 31-35, 1961.

MIYADA, V. S. A levedura seca na alimentação de suínos: estudos adicionais sobre o seu valor protéico e vitamínico. Piracicaba, 1987. 159p. Tese (Livre Docência) - Escola Superior de Agricultura Luiz de Queiroz, Universidade São Paulo.

MOREIRA, I.; ROSTAGNO, H. S.; COELHO, D., T. et al. Determinação dos Coeficientes de Digestibilidade, Valores Energéticos e Índices de Controle de Qualidade do Milho e Soja Integral Processados a Calor. Revista da Sociedade Brasileira de Zootecnia, v. 23, n. 6, p.916-929, 1994.

MURAD, J. C. B. Viabilidade da farinha de ovos na alimentação de suínos. Lavras, 1991. 69p. Dissertação (Mestrado) - Universidade Federal de Lavras. 
NABER, E. C. Cholesterol content of eggs: can and should the industry try to change it? Feedstuffs, v. 62, n. 5, p. 46-52, 1990.

NASCIMENTO FILHO, V. F.; ABDALA, A. L.; KORNDORFER, C. M. et al. Sensibilidades analíticas de diferentes modos de excitação em fluorescência de raios $\mathrm{X}$ para medida de trançadores em fezes de animais. In: ENCONTRO CIENTÍFICO DOS PÓSGRADUANDOS DO CENA/USP, Piracicaba, 1997. Resumos. Piracicaba: CENA, 1997. p. 69.

NESSMITH, W. B.; TOKACH, M. D.; GOODBAND, R. D. et al. Evaluation of various specialty protein sources as replacements for spray-dried animal plasma in diets for segregated early-weaned pigs. Kansas State University Swine Day Research Report, p. 34-39, 1996.

NELSON, D. L.; COX, M. M. Lehninger principles of biochemistry. 3 ed. New York: Worth Publishers, 2000. cap. 18, p. 623-658: Amino acid oxidation and the production of urea.

NORIN, S. L.; MILLER, P. S.; LEWIS, A. J. et al. Protein sources for segregated early weaned pigs. Journal of Animal Science, v. 76, suppl. 2, p.49, 1998.

NUNES, R. V.; BUTERI, C. B.; NUNES, C. G. V. et al. Fatores Antinutricionais dos ingredientes destinados à alimentação animal. In:. SIMPÓSIO SOBRE INGREDIENTES NA ALIMENTAÇÃO ANIMAL, Campinas, 2001. Anais. Campinas: CBNA, 2001. p. 235-272.

OHBA, R.; TERAMOTO, Y.; UEDA, S. Clarification of spray - dried egg yolk suspensions and solubilization of proteins from lipoproteins. Journal of Food Science, v. 58, n.2, p. 307-309, 1993. 
OWEN, K. Q.; NELSSEN, J. L.; GOODBAND, R. D. et al. Effects of various fractions of spray-dried plasma on performance of early weaned pigs. Journal of Animal Science, v.73, suppl. 1, p.81, 1995.

OWEN, K. Q.; NELSSEN, J. L.; TOKACH, M. D. et al. Spray - dried egg protein in early weaned starter pig diets. Journal of Animal Science. v. 71, p.58, 1993.

OWSLEY, W. F.; ORR, D. E.; TRIBBLE, L. F. Effects of age and diet on the development of the pancreas and the syntesis nas secretion of pancreatic enzymes in the young pig. Journal of Animal Science, v. 63, n. 2, p. 497-504, 1986.

OWUSU-ASIEDU, A.; MARQUARDT, R. R.; NYACHOTI, C. M. et al. Response of earlyweaned pigs to pea protein isolate-based diets supplemented with chicken egg-yolk anti-E coli (K88) antibody. http://www.asas.org/jas/jointabs/iaafsc11.pdf (15 fev. 2002).

PEKAS, J. C. Digestion and absorption capacity and their development. In: MILLER, E. R.; ULTREY, D. E.; LEWIS, A. J. (Ed.). Swine nutrition Stonehan: ButterworthHeinemann, 1991. cap. 3, p.37-73.

PEINIAU, J.; AUMAITR, A.; LEBRETON, Y. Effects of dietary protein sources differing of nitrogen and pancreatic enzymes activity in early weaned pigs. Livestock Production Science, v. 45, p. 197-208, 1996.

PENZ, A. M. J.; VIOLA, E. S. Nutrição. In: SOBESTIANSKI, J; WENTZ, I; SILVEIRA, P. R. S, et al. (Ed.) Suinocultura intensiva: produção, manejo e saúde do rebanho. Brasília: Embrapa; Concórdia: Embrapa-CNPSA, 1998, cap. 3, p. 47-63. 
PEO Jr, E. R.; EVERTSON, D. M.; WEHRBEIN, G. F. et. al. Dried whole egg as a source of supplement protein for baby pigs. Journal of Animal Science, v. 29, p. 141, 1969.

PIERCE, J. L.; CROMWELL, G. L.; LINDEMANN, M. D. Assessment of three fractions of spray-dried porcine plasma on performance of early-weaned pigs. Journal of Animal Science, v.73, suppl. 1, p.81, 1995.

PLUSKE, J. R.; HAMPSON, D. J.; WILLIAMS, I. H. Factors influencing the structure and function of the small intestine in the weaned pig: a review. Livestock Production Science, v. 51, p. 215-236, 1997.

POND, W. G.; MERSMANN, H. J. Serum cholesterol response to diet cholesterol in genetically obese and lean weanling pigs. Journal of Animal Science, v. 68, suppl. 1, p.374, 1990.

PRECIADO, L. C. L. A salinomicina como estimulante do crescimento de suínos em recria. Piracicaba, 1990. 55p. Dissertação (Mestrado) - Escola Superior de Agricultura Luiz de Queiroz, Universidade São Paulo.

PUPA, J. M. R; ROSTAGNO, H. S.; GOMES, P. C. et al. Determinação da digestibilidade dos nutrientes e da energia de alimentos utilizados em dietas para leitões. In: CONGRESSO BRASILEIRO DE VETERINÁRIOS ESPECIALISTAS EM SUÍNOS, 9. Belo Horizonte, 1999. Resumos. Belo Horizonte: MINASCENTRO, 1999. p. 409-410.

RANZEM, B. K.; RANZEM, D.; MATIC, S. et al.. Chemical and organoleptic properties of irradiated dried whole egg and egg yolk. Journal of Food Protection, v. 52, p. 781 - 789 , 1989. 
RIZVI, S.; HARBOUR; D. A., PEARSON; G. R. et al. The use of hyper-immunised egg as a source of prophylactic antibodies in the neonatal piglet. http://www.bsas.org.uk/meetings/annlproc/Pdf2001/023.pdf. (13 jan. 2002).

ROSTAGnO, H. S.; ALBINO, L. F. T.; DONZELE, J. L. et al. Tabelas brasileiras para aves e suínos: composição de alimentos e exigências nutricionais. Viçosa: Universidade de Viçosa, 2000. 141p.

SAS INSTITUTE. SAS user’s guide: version 6.11. Cary, 1996. 956p.

SHIELDS Jr., R., G.; EKSTROM, K. E.; MAHAN, D., C. Effect of weaning age and feeding method on digestive enzyme development in swine from birth to ten weeks Journal of Animal Science, v. 50, n.1, 1980.

SCHMIDT, L. D.; NYACHOTI, C.M.; BOROS, D. et al. The potentian for egg by-products to replace spray-dried porcine plasma in early-weaned piglet diets. http://www.asas.org/jas/jointabs/iaafs153.pdf (15fev. 2002).

SERRANO, V. O. S. Digestibilidade dos aminoácidos de suplementos protéicos em suínos submetidos ou não a anastomose íleo-retal. Viçosa, 1989. 55p. Dissertação (Mestrado) Universidade Federal de Viçosa.

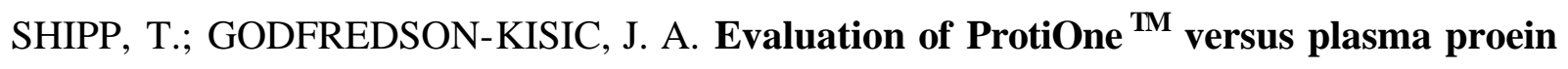
for two-week-old weanling pigs. http://www.asas.org/jas/00meet/part18.pdf (15 fev. 2002).

SILVA, D. J. Análise de alimentos (Métodos químicos e biológicos). 2. ed. Viçosa: UFV, $1990,165 \mathrm{p}$. 
SPACKMAN, D. C.; STEIN, W. H.; MOORE, S. Automatic recording apparatus for use in the chromatography of aminoacids. Analytical Biochemistry, v. 30, p. 1190-1206, 1958.

TSAI, S. T.; HUDSON, C. A. Cholesterol oxides in commercial dry egg products: isolation and identification. Journal of Food Science, v. 49, p. 1245-1248, 1984.

TSAI, S. T.; HUDSON, C. A. Cholesterol oxides in commercial dry egg products: quantitation. Journal of Food Science, v. 50, p. 229-232, 1985.

VAN DIJK, A. J.; EVERTS, M. J. A.; NABUURS, M. J. A. et al. Growth performance of wealing pigs fed spray-dried animal plasma: a review. Livestock Production Science, v. 68, p. 263-274, 2001.

VAN NEVEL, C.;DE RYCKE, H.; BEECKMANS, S. et. al. Inhibitory action of spray-dried blood plasma and whole egg powder on lectins in extracts of several legume seeds: a qulitative approach. Journal Science and Food of Agriculture, v. 77, p. 319-326, 1998.

VAN NEVEL, C.; SEYNAEVE, M.; VAN DE VOORDE, G. et al. Effects of increasind amounts of Lupinus albus seeds without or with whole egg powder in the diet og growing pigs on performance. Animal Feed Science and Technology, v. 83, p. 89-101, 2000.

VIEIRA, E. C. Os valores do ovo. Avicultura Industrial, v. 90, p. 17-19, mar. 2000.

WEAVER, E. M.; RUSSELL, L. E.; DREW M. D. The effect os spray-dried animal plasma fractions on performance of newly weaned pigs. Journal of Animal Science, v.73, suppl. $1, \mathrm{p} .81,1995$. 
APÊNDICES 
Tabela A1. Cálculo da restrição alimentar dos animais durante o período de adaptação (Experimento I).

\begin{tabular}{lcccccc}
\hline Tratamento & $\begin{array}{c}\text { Peso } \\
(\mathrm{kg})\end{array}$ & $\begin{array}{c}\text { Peso } \\
\text { metabólico }^{\text {a }}\end{array}$ & $\begin{array}{c}\text { Consumo } \\
\text { diário }(\mathrm{kg})\end{array}$ & $\begin{array}{c}\text { Índice } \\
\text { individual }^{\mathrm{b}}\end{array}$ & $\begin{array}{c}\text { Menor } \\
\text { índice }\end{array}$ & $\begin{array}{c}\text { Consumo } \\
\text { restrito }(\mathrm{kg})\end{array}$ \\
\hline Basal 1 & 17,0 & 8,37 & 915 & 109,246 & 82,93 & 694 \\
Basal 2 & 14,5 & 7,43 & 728 & 98,033 & 82,93 & 616 \\
Basal 3 & 15,7 & 7,88 & 909 & 115,240 & 82,93 & 654 \\
Basal 4 & 14,9 & 7,58 & 629 & 82,930 & 82,93 & 629 \\
Teste 1 & 13,9 & 7,20 & 745 & 103,489 & 82,93 & 597 \\
Teste 2 & 18,3 & 8,85 & 928 & 104,828 & 82,93 & 734 \\
Teste 3 & 15,8 & 7,93 & 702 & 88,607 & 82,93 & 657 \\
Teste 4 & 17,5 & 8,56 & 919 & 107,382 & 82,93 & 710 \\
\hline
\end{tabular}

${ }^{a}$ Peso metabólico $=$ Peso vivo ${ }^{0,75}$

${ }^{\mathrm{b}}$ Indice individual $=$ Consumo $/$ peso metabólico

${ }^{\mathrm{c}}$ Consumo restrito $=$ Peso metabólico de cada animal $\mathrm{x}$ menor índice individual 
Tabela A2. Ganhos diários de pesos (GDP, kg), consumos diários de ração (CDR, kg) e conversões alimentares (CA) dos animais, referente à fase pré-inicial (1-14 dias pós-desmame) (Experimento II) ${ }^{\mathrm{a}}$.

\begin{tabular}{|c|c|c|c|c|c|c|}
\hline \multirow[b]{2}{*}{ Variável } & \multirow[b]{2}{*}{ Bloco } & \multicolumn{5}{|c|}{ Níveis de substituição protéica do PS pelo OP, \% } \\
\hline & & 0 & 25 & 50 & 75 & 100 \\
\hline \multirow{10}{*}{ GDP, $\mathrm{kg}$} & 1 & 0,236 & 0,136 & 0,243 & 0,100 & 0,061 \\
\hline & 2 & 0,111 & 0,107 & 0,164 & 0,111 & 0,100 \\
\hline & 3 & 0,171 & 0,118 & 0,125 & 0,086 & 0,068 \\
\hline & 4 & 0,168 & 0,275 & 0,243 & 0,186 & 0,225 \\
\hline & 5 & 0,136 & 0,204 & 0,175 & 0,150 & 0,196 \\
\hline & 6 & 0,168 & 0,143 & 0,150 & 0,175 & 0,211 \\
\hline & 7 & 0,204 & 0,196 & 0,218 & 0,186 & 0,196 \\
\hline & 8 & 0,154 & 0,221 & 0,182 & 0,236 & 0,157 \\
\hline & 9 & 0,225 & 0,261 & 0,207 & 0,218 & 0,132 \\
\hline & Média & 0,175 & 0,185 & 0,190 & 0,161 & 0,150 \\
\hline \multirow{10}{*}{ CDR, $\mathrm{kg}$} & 1 & 0,395 & 0,302 & 0,414 & 0,302 & 0,316 \\
\hline & 2 & 0,236 & 0,237 & 0,338 & 0,276 & 0,308 \\
\hline & 3 & 0,295 & 0,235 & 0,288 & 0,241 & 0,191 \\
\hline & 4 & 0,307 & 0,417 & 0,408 & 0,318 & 0,319 \\
\hline & 5 & 0,282 & 0,270 & 0,303 & 0,278 & 0,306 \\
\hline & 6 & 0,263 & 0,277 & 0,274 & 0,335 & 0,292 \\
\hline & 7 & 0,334 & 0,346 & 0,357 & 0,279 & 0,353 \\
\hline & 8 & 0,334 & 0,334 & 0,340 & 0,429 & 0,380 \\
\hline & 9 & 0,372 & 0,396 & 0,324 & 0,338 & 0,338 \\
\hline & Média & 0,313 & 0,313 & 0,338 & 0,311 & 0,311 \\
\hline \multirow{10}{*}{$\mathrm{CA}$} & 1 & 1,68 & 2,23 & 1,70 & 3,02 & 5,21 \\
\hline & 2 & 2,14 & 2,21 & 2,06 & 2,50 & 3,08 \\
\hline & 3 & 1,72 & 2,00 & 2,30 & 2,81 & 2,82 \\
\hline & 4 & 1,83 & 1,52 & 1,68 & 1,71 & 1,42 \\
\hline & 5 & 2,08 & 1,33 & 1,73 & 1,85 & 1,56 \\
\hline & 6 & 1,56 & 1,94 & 1,83 & 1,91 & 1,39 \\
\hline & 7 & 1,64 & 1,76 & 1,64 & 1,50 & 1,80 \\
\hline & 8 & 2,17 & 1,51 & 1,87 & 1,82 & 2,42 \\
\hline & 9 & 1,65 & 1,52 & 1,56 & 1,55 & 2,55 \\
\hline & Média & 1,79 & 1,78 & 1,82 & 2,07 & 2,47 \\
\hline
\end{tabular}

${ }^{\mathrm{a}}$ Valores individuais representam as médias de dois animais por unidade experimental 
Tabela A3. Ganhos diários de pesos (GDP, kg), consumos diários de ração (CDR, kg) e conversões alimentares (CA) dos animais, referente à fase inicial (15-28 dias pósdesmame) (Experimento II) ${ }^{\mathrm{a}}$.

\begin{tabular}{|c|c|c|c|c|c|c|}
\hline \multirow[b]{2}{*}{ Variável } & \multirow[b]{2}{*}{ Bloco } & \multicolumn{5}{|c|}{ Níveis de substituição protéica do PS pelo OP, \% } \\
\hline & & 0 & 25 & 50 & 75 & 100 \\
\hline \multirow{10}{*}{ GDP, kg } & 1 & 0,614 & 0,475 & 0,561 & 0,486 & 0,454 \\
\hline & 2 & 0,536 & 0,329 & 0,579 & 0,393 & 0,268 \\
\hline & 3 & 0,543 & 0,446 & 0,489 & 0,475 & 0,389 \\
\hline & 4 & 0,543 & 0,521 & 0,589 & 0,425 & 0,389 \\
\hline & 5 & 0,479 & 0,554 & 0,507 & 0,454 & 0,386 \\
\hline & 6 & 0,536 & 0,571 & 0,457 & 0,475 & 0,421 \\
\hline & 7 & 0,607 & 0,593 & 0,557 & 0,557 & 0,489 \\
\hline & 8 & 0,646 & 0,579 & 0,604 & 0,579 & 0,664 \\
\hline & 9 & 0,679 & 0,707 & 0,575 & 0,579 & 0,554 \\
\hline & Média & 0,576 & 0,531 & 0,546 & 0,491 & 0,446 \\
\hline \multirow{10}{*}{ CDR, $\mathrm{kg}$} & 1 & 0,904 & 0,718 & 0,879 & 0,797 & 0,698 \\
\hline & 2 & 0,802 & 0,613 & 0,795 & 0,597 & 0,467 \\
\hline & 3 & 0,825 & 0,662 & 0,808 & 0,718 & 0,601 \\
\hline & 4 & 0,918 & 0,928 & 0,970 & 0,699 & 0,682 \\
\hline & 5 & 0,750 & 0,817 & 0,762 & 0,722 & 0,640 \\
\hline & 6 & 0,776 & 0,924 & 0,736 & 0,770 & 0,685 \\
\hline & 7 & 0,991 & 0,874 & 0,825 & 0,820 & 0,793 \\
\hline & 8 & 0,999 & 0,906 & 0,906 & 0,987 & 1,017 \\
\hline & 9 & 1,041 & 1,121 & 0,861 & 0,823 & 0,917 \\
\hline & Média & 0,890 & 0,840 & $\mathbf{0 , 8 3 8}$ & 0,770 & 0,722 \\
\hline \multirow{10}{*}{$\mathrm{CA}$} & 1 & 1,47 & 1,51 & 1,57 & 1,64 & 1,54 \\
\hline & 2 & 1,50 & 1,87 & 1,37 & 1,52 & 1,74 \\
\hline & 3 & 1,52 & 1,48 & 1,65 & 1,51 & 1,54 \\
\hline & 4 & 1,69 & 1,78 & 1,65 & 1,65 & 1,75 \\
\hline & 5 & 1,57 & 1,48 & 1,50 & 1,59 & 1,66 \\
\hline & 6 & 1,45 & 1,62 & 1,61 & 1,62 & 1,63 \\
\hline & 7 & 1,63 & 1,47 & 1,48 & 1,47 & 1,62 \\
\hline & 8 & 1,54 & 1,57 & 1,50 & 1,71 & 1,53 \\
\hline & 9 & 1,53 & 1,59 & 1,50 & 1,42 & 1,66 \\
\hline & Média & 1,55 & 1,60 & 1,54 & 1,57 & 1,54 \\
\hline
\end{tabular}

${ }^{\mathrm{a}}$ Valores individuais representam as médias de dois animais por unidade experimental 
Tabela A4. Ganhos diários de pesos (GDP, kg), consumos diários de ração (CDR, kg) e conversões alimentares (CA) dos animais, referente ao período total (0-28 dias pós-desmame) (Experimento II) ${ }^{\mathrm{a}}$.

\begin{tabular}{|c|c|c|c|c|c|c|}
\hline \multirow[b]{2}{*}{ Variável } & \multirow[b]{2}{*}{ Bloco } & \multicolumn{5}{|c|}{ Níveis de substituição protéica do PS pelo OP, \% } \\
\hline & & 0 & 25 & 50 & 75 & 100 \\
\hline \multirow{10}{*}{ GDP, $\mathrm{kg}$} & 1 & 0,425 & 0,305 & 0,402 & 0,293 & 0,257 \\
\hline & 2 & 0,323 & 0,218 & 0,371 & 0,252 & 0,184 \\
\hline & 3 & 0,357 & 0,282 & 0,307 & 0,280 & 0,229 \\
\hline & 4 & 0,355 & 0,398 & 0,416 & 0,305 & 0,307 \\
\hline & 5 & 0,307 & 0,379 & 0,341 & 0,302 & 0,291 \\
\hline & 6 & 0,352 & 0,357 & 0,304 & 0,325 & 0,316 \\
\hline & 7 & 0,405 & 0,395 & 0,388 & 0,371 & 0,343 \\
\hline & 8 & 0,400 & 0,400 & 0,393 & 0,407 & 0,411 \\
\hline & 9 & 0,452 & 0,479 & 0,391 & 0,398 & 0,343 \\
\hline & Média & 0,375 & 0,357 & 0,368 & 0,326 & 0,298 \\
\hline \multirow{10}{*}{ CDR, kg } & 1 & 0,649 & 0,510 & 0,646 & 0,549 & 0,507 \\
\hline & 2 & 0,519 & 0,425 & 0,567 & 0,437 & 0,388 \\
\hline & 3 & 0,560 & 0,448 & 0,548 & 0,479 & 0,396 \\
\hline & 4 & 0,687 & 0,697 & 0,750 & 0,553 & 0,555 \\
\hline & 5 & 0,540 & 0,578 & 0,594 & 0,548 & 0,515 \\
\hline & 6 & 0,579 & 0,600 & 0,557 & 0,578 & 0,517 \\
\hline & 7 & 0,656 & 0,627 & 0,601 & 0,559 & 0,565 \\
\hline & 8 & 0,663 & 0,607 & 0,614 & 0,708 & 0,684 \\
\hline & 9 & 0,683 & 0,734 & 0,595 & 0,580 & 0,627 \\
\hline & Média & 0,615 & $\mathbf{0 , 5 8 1}$ & 0,608 & 0,555 & 0,528 \\
\hline \multirow{10}{*}{$\mathrm{CA}$} & 1 & 1,53 & 1,67 & 1,61 & 1,88 & 1,97 \\
\hline & 2 & 1,61 & 1,95 & 1,53 & 1,73 & 2,11 \\
\hline & 3 & 1,57 & 1,59 & 1,78 & 1,71 & 1,73 \\
\hline & 4 & 1,93 & 1,75 & 1,80 & 1,81 & 1,81 \\
\hline & 5 & 1,76 & 1,53 & 1,74 & 1,81 & 1,77 \\
\hline & 6 & 1,65 & 1,68 & 1,83 & 1,78 & 1,64 \\
\hline & 7 & 1,62 & 1,59 & 1,55 & 1,51 & 1,65 \\
\hline & 8 & 1,66 & 1,52 & 1,56 & 1,74 & 1,66 \\
\hline & 9 & 1,51 & 1,53 & 1,52 & 1,46 & 1,83 \\
\hline & Média & 1,65 & 1,65 & 1,66 & 1,71 & 1,80 \\
\hline
\end{tabular}

${ }^{\mathrm{a}}$ Valores individuais representam as médias de dois animais por unidade experimental 
Tabela A5. Médias dos níveis plasmáticos de uréia (UR, mg/100ml), proteína total (PT, mg/100ml), albumina (AL, mg/100ml), globulina (GL mg/100ml), relação albumina/globulina (AL/GL), triglicérides (TG, mg/100ml) e colesterol (COL, $\mathrm{mg} / 100 \mathrm{ml}$ ) e dos níveis sanguíneos de hemoglobina (Hg, mg/100ml) e hematócrito $(\mathrm{Ht}, \%)$. (Experimento II) ${ }^{\mathrm{a}}$.

\begin{tabular}{|c|c|c|c|c|c|c|c|c|c|c|}
\hline Tratamentos & Blocos & UR & PT & $\mathrm{AL}$ & GL & AL/GL & TG & $\mathrm{COL}$ & $\mathrm{Hg}$ & $\mathrm{Ht}$ \\
\hline \multirow{10}{*}{$0 \%$} & 1 & 24,5 & 5,35 & 3,90 & 1,45 & 2,75 & 18,0 & 89,5 & 12,6 & 40,10 \\
\hline & 2 & 21,0 & 5,65 & 4,15 & 1,50 & 2,80 & 21,5 & 79,0 & 12,9 & 41,35 \\
\hline & 3 & 25,5 & 5,15 & 3,45 & 1,70 & 2,05 & 48,0 & 80,5 & 12,2 & 38,45 \\
\hline & 4 & 42,0 & 5,70 & 3,60 & 2,10 & 1,70 & 25,5 & 96,5 & 11,5 & 36,20 \\
\hline & 5 & 28,0 & 5,45 & 3,55 & 1,90 & 1,90 & 46,0 & 78,0 & 11,5 & 36,45 \\
\hline & 6 & 36,0 & 5,25 & 3,30 & 1,95 & 1,75 & 23,0 & 89,0 & 11,5 & 36,90 \\
\hline & 7 & 44,5 & 5,60 & 3,40 & 2,20 & 1,55 & 25,5 & 87,0 & 11,7 & 37,45 \\
\hline & 8 & 40,0 & 5,65 & 3,90 & 1,75 & 2,35 & 33,5 & 105,0 & 12,0 & 38,65 \\
\hline & 9 & 44,0 & 5,95 & 4,10 & 1,85 & 2,20 & 19,5 & 121,0 & 11,8 & 38,15 \\
\hline & Média & 33,9 & 5,53 & 3,71 & 1,82 & 2,12 & 28,9 & 91,7 & 11,9 & 38,19 \\
\hline \multirow{10}{*}{$25 \%$} & 1 & 21,0 & 5,05 & 3,45 & 1,60 & 2,20 & 33,5 & 90,5 & 11,5 & 36,35 \\
\hline & 2 & 28,5 & 6,15 & 3,40 & 2,75 & 1,30 & 30,0 & 87,0 & 8,75 & 28,35 \\
\hline & 3 & 30,5 & 5,35 & 3,50 & 1,85 & 1,90 & 31,0 & 73,5 & 11,7 & 36,40 \\
\hline & 4 & 39,0 & 5,75 & 3,90 & 1,85 & 2,10 & 37,0 & 91,5 & 10,8 & 34,65 \\
\hline & 5 & 26,5 & 5,60 & 3,85 & 1,75 & 2,30 & 32,5 & 93,5 & 12,4 & 39,35 \\
\hline & 6 & 24,0 & 5,80 & 3,80 & 2,00 & 1,90 & 50,0 & 73,0 & 11,9 & 37,90 \\
\hline & 7 & 28,0 & 5,45 & 3,65 & 1,80 & 2,10 & 29,5 & 90,0 & 25,2 & 25,40 \\
\hline & 8 & 31,5 & 5,45 & 3,80 & 1,65 & 2,35 & 27,0 & 87,0 & 11,8 & 37,75 \\
\hline & 9 & 32,0 & 5,85 & 4,10 & 1,75 & 2,35 & 26,0 & 98,5 & 12,5 & 39,75 \\
\hline & Média & 29,0 & 5,61 & 3,72 & 1,89 & 2,06 & 32,9 & 87,2 & 12,9 & 35,10 \\
\hline \multirow{10}{*}{$50 \%$} & 1 & 30,0 & 5,50 & 3,65 & 1,85 & 2,00 & 25,0 & 101,5 & 11,5 & 36,40 \\
\hline & 2 & 20,5 & 5,40 & 3,65 & 1,75 & 2,15 & 38,5 & 92,0 & 11,7 & 37,00 \\
\hline & 3 & 30,5 & 5,10 & 3,40 & 1,70 & 2,00 & 25,0 & 77,0 & 12,3 & 39,00 \\
\hline & 4 & 31,0 & 5,75 & 3,95 & 1,80 & 2,30 & 25,5 & 80,5 & 12,4 & 39,35 \\
\hline & 5 & 25,5 & 5,45 & 3,80 & 1,65 & 2,30 & 25,5 & 96,0 & 12,9 & 40,55 \\
\hline & 6 & 25,0 & 5,55 & 3,65 & 1,90 & 1,95 & 23,0 & 94,0 & 10,8 & 32,75 \\
\hline & 7 & 25,0 & 5,45 & 3,60 & 1,85 & 1,95 & 24,0 & 87,0 & 12,1 & 37,15 \\
\hline & 8 & 32,5 & 5,55 & 3,75 & 1,80 & 2,10 & 26,0 & 93,5 & 12,1 & 39,40 \\
\hline & 9 & 29,0 & 5,85 & 3,55 & 2,30 & 1,55 & 29,0 & 103,5 & 12,5 & 40,75 \\
\hline & Média & 27,7 & 5,51 & 3,67 & 1,84 & 2,03 & 26,8 & 91,7 & 12,0 & 38,04 \\
\hline
\end{tabular}


Tabela A5. Médias dos níveis plasmáticos de uréia (UR, mg/100ml), proteína total (PT, mg/100ml), albumina (AL, mg/100ml), globulina (GL mg/100ml), relação albumina/globulina (AL/GL), triglicérides (TG, mg/100ml) e colesterol (COL, $\mathrm{mg} / 100 \mathrm{ml}$ ) e dos níveis sanguíneos de hemoglobina (Hg, mg/100ml) e hematócrito $(\mathrm{Ht}, \%)$. (Experimento II) $)^{\mathrm{a}}$.

\begin{tabular}{ccccccccccc}
\hline Tratamentos & Blocos & UR & PT & AL & GL & AL/GL & TG & COL & Hg & Ht \\
\hline & 1 & 21,0 & 5,15 & 3,55 & 1,60 & 2,25 & 30,0 & 103,5 & 12,3 & 39,35 \\
& 2 & 23,0 & 5,80 & 3,95 & 1,85 & 2,25 & 44,5 & 97,5 & 9,8 & 31,65 \\
& 3 & 18,5 & 5,55 & 3,95 & 1,60 & 2,70 & 33,5 & 78,5 & 11,9 & 37,55 \\
$75 \%^{\text {b }}$ & 4 & 35,5 & 5,40 & 3,50 & 1,90 & 1,90 & 46,0 & 73,5 & 10,4 & 32,80 \\
& 5 & - & - & - & - & - & - & - & - & - \\
& 6 & 41,0 & 5,15 & 3,55 & 1,60 & 2,25 & 34,0 & 72,0 & 11,4 & 35,65 \\
& 7 & 28,0 & 5,30 & 3,30 & 2,00 & 1,65 & 22,5 & 78,5 & 12,2 & 38,05 \\
& 8 & 26,0 & 5,30 & 3,50 & 1,80 & 1,90 & 28,0 & 76,0 & 11,7 & 32,50 \\
& 9 & 24,0 & 5,45 & 3,70 & 1,75 & 2,10 & 34,5 & 87,0 & 12,8 & 41,10 \\
& Média & $\mathbf{2 4 , 1}$ & $\mathbf{4 , 7 9}$ & $\mathbf{3 , 2 2}$ & $\mathbf{1 , 5 7}$ & $\mathbf{1 , 8 9}$ & $\mathbf{3 0 , 3}$ & $\mathbf{7 4 , 1}$ & $\mathbf{1 0 , 3}$ & $\mathbf{3 2 , 0 7}$ \\
& & & & & & & & & & \\
& 1 & 20,5 & 4,80 & 3,50 & 1,30 & 2,7 & 35,0 & 90,5 & 11,5 & 36,5 \\
& 2 & 22,0 & 5,50 & 3,90 & 1,60 & 2,4 & 34,0 & 114,0 & 13,2 & 42,10 \\
& 3 & 31,5 & 5,20 & 3,85 & 1,35 & 2,85 & 36,0 & 67,5 & 12,0 & 35,45 \\
& 4 & 37,0 & 5,35 & 3,55 & 1,80 & 1,95 & 55,5 & 72,5 & 12,0 & 38,55 \\
& 5 & 24,0 & 5,20 & 3,65 & 1,55 & 2,35 & 43,5 & 99,5 & 12,0 & 37,50 \\
& 6 & 28,0 & 5,05 & 3,45 & 1,60 & 2,25 & 30,5 & 72,0 & 12,0 & 36,45 \\
& 7 & 37,5 & 5,85 & 3,40 & 2,45 & 1,7 & 44,0 & 69,5 & 11,3 & 34,90 \\
& 8 & 29,0 & 5,70 & 3,90 & 1,80 & 2,15 & 27,5 & 100,5 & 11,8 & 38,10 \\
& 9 & 41,0 & 5,30 & 3,70 & 1,60 & 2,3 & 26,0 & 105,0 & 13,2 & 41,50 \\
& Média & $\mathbf{3 0 , 1}$ & $\mathbf{5 , 3 3}$ & $\mathbf{3 , 6 6}$ & $\mathbf{1 , 6 7}$ & $\mathbf{2 , 2 9}$ & $\mathbf{3 6 , 9}$ & $\mathbf{8 7 , 8 9}$ & $\mathbf{1 2 , 1}$ & $\mathbf{3 7 , 8 9}$ \\
\hline
\end{tabular}

${ }^{a}$ Valores individuais representam as médias de dois animais por unidade experimental

${ }^{\mathrm{b}}$ Substituição protéica do plasma sanguíneo pelo ovo em pó 